النظام السياسي في المملكة العربية السعودية وجمهورية إيران الإسلامية

$$
\text { روئية مقارنة }
$$

$$
\begin{aligned}
& \text { عبدالرزلق خلف محمد الطائي } \\
& \text { مدرس مساعد مركز الدراسات الإقليمية/ جامعة الموصل ململ }
\end{aligned}
$$

مستخلص البحث

يختلف النظام الملكي في المملكة العربية السعودية عن بقية الأنظمـة الملكية في العالم، كما يختلف النظام الجمهوري الإسلامي في إيران عن باقي الأنظمـة الجمهوريـة

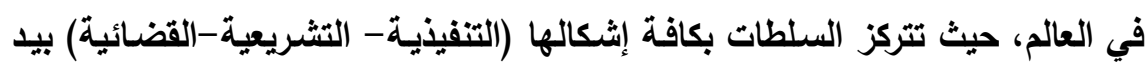
شخص واحد هو الولي الفقيه المرشد الأعلى وهو منصب لا يوجد إلا في إيران، في

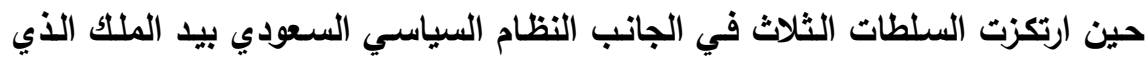

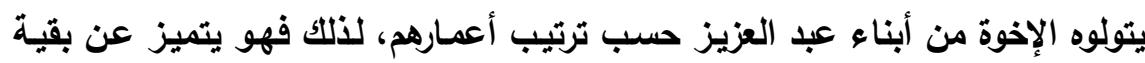
الأنظمة الملكية، ويكتسب نظامي الحكم أهمية بالغة وذلك لمكانة المؤسسة الداينية في كلا البلدين .

المقدمة

يكتسـب طبيعـة النظـام السياسـي القـائم في المملكـة العربيـة السـعودية

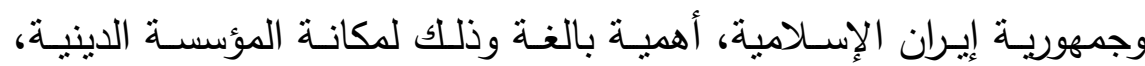
وتأثنرها على النظام السياسي في كلا الدولتين. فبعد عقد تحالف ديني وسياسي ناجح بين محمد بن سعود - مؤسس

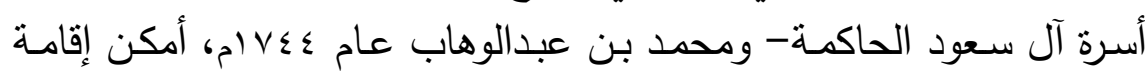

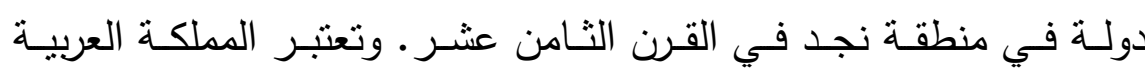

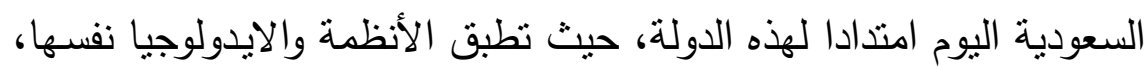

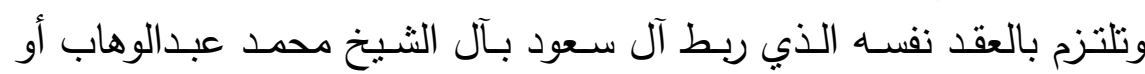


بأحفاده. أما إيران ففي النصف الثاني من القرن الخامس عشر جرت فيها

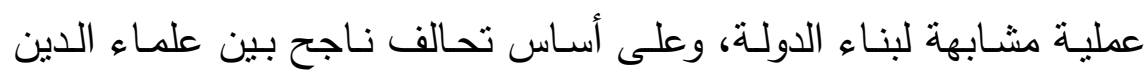
الثيعة - المنتمين إلى القبائل التركمانية- وأسرة الصوفيين الحاكمـة. ونجح

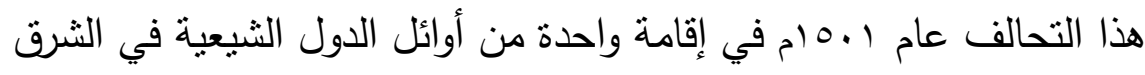

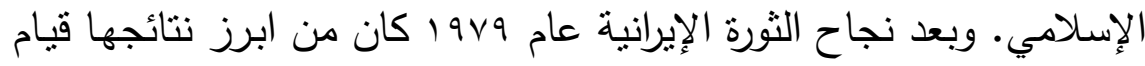

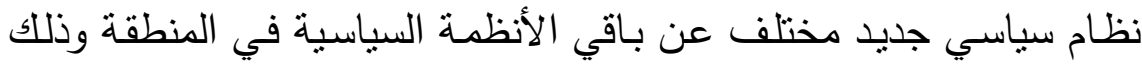
بسبب تعدد وتذاخل مؤسساته.

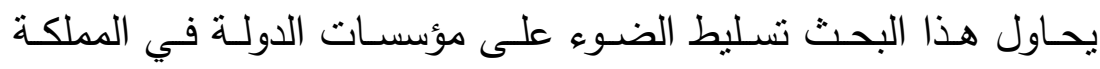
العربية السعودية والجمهوريـة الإسـلامية في إيران من رؤيسة مقارنـة وقد تم

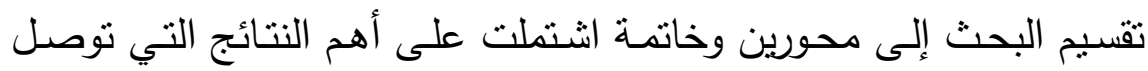
إلبيها البحث.

الأول: النظام السياسي في المملكة العربية السعودية. الثاني: النظام السياسي في الجمهورية الإسـامية في إيران.

الأول: النظام السياسي في المملكة العربية السعودية

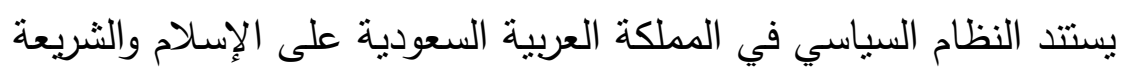

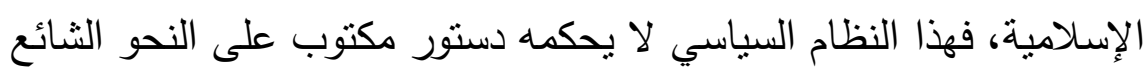

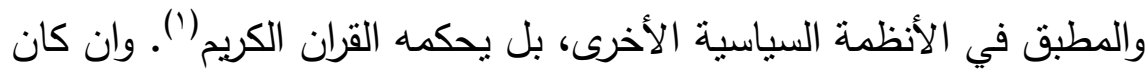

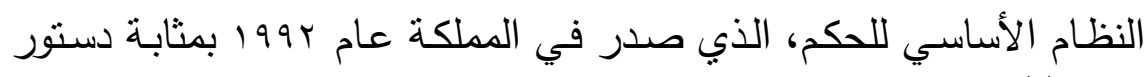

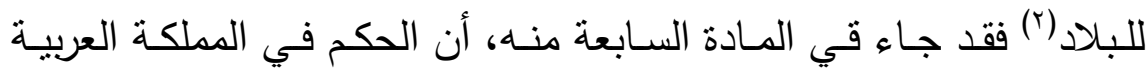

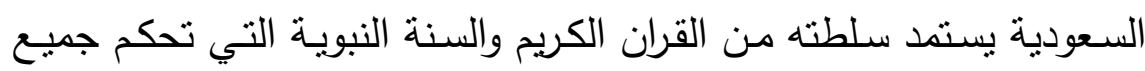

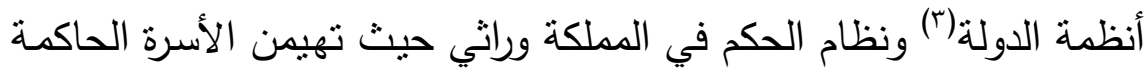

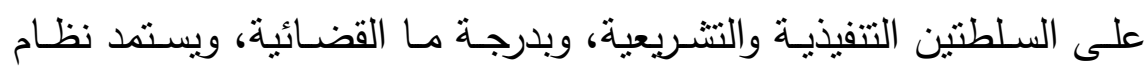
الحكم شرعيته من مصدرين أساسيين هما الإسلام والتقاليد القبلية(؟). 
فالنظام السياسي في المملكة مازال ملتزماً بالميثاق الذي تم عقده عام

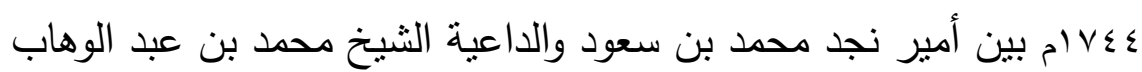

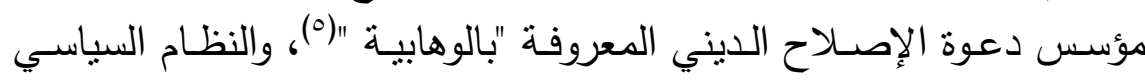

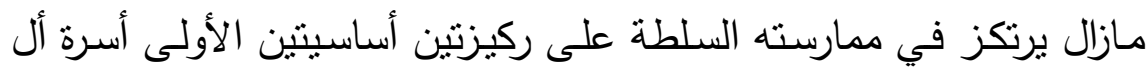

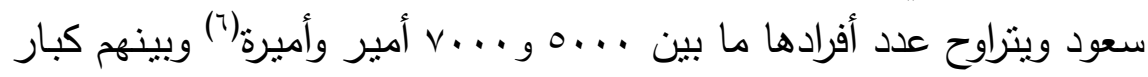
المسؤولين الذين مازالوا لهم دورا حاسما في في القران القرار السياسي للمملكة. ويأني

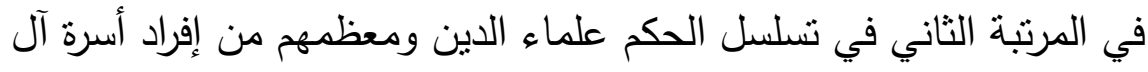

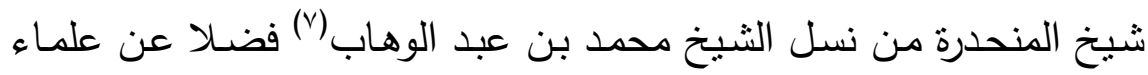

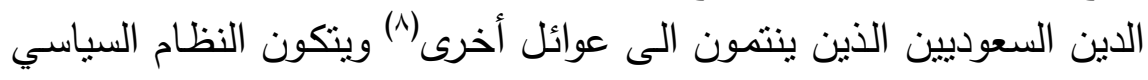
في المملكة العربية من المؤسسات الآتية:

أولا: الملك بلد

بدأ نبلور (الملك) كمؤسسة سياسية فعلية مع صدور الأمر الملكي المرقم

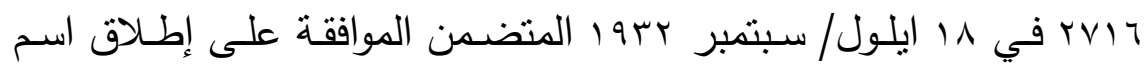

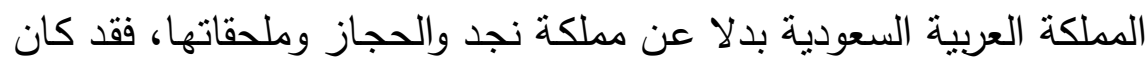

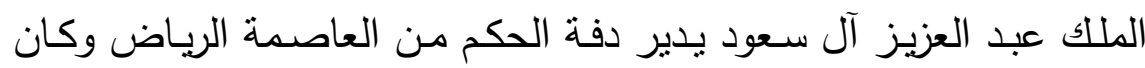

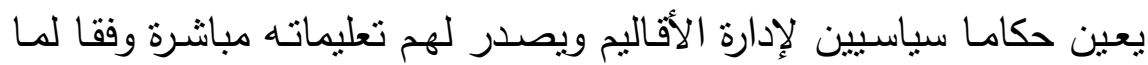

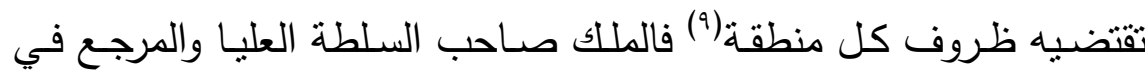

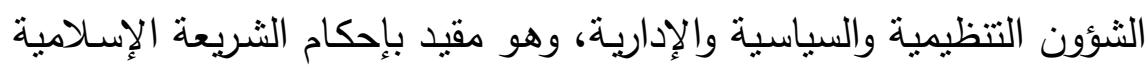

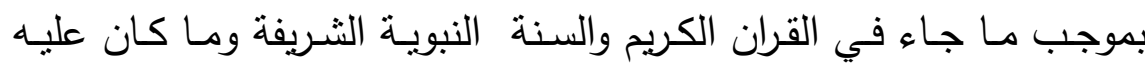

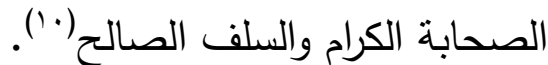
إن هذا الدور المناط بالملك كان قد تعمق عمليا أكثر من خلال نوليه

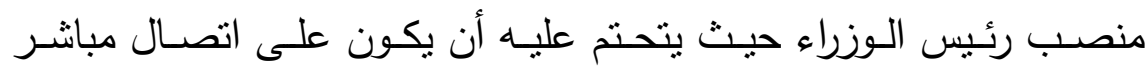
بالأوضاع العامة في البلاد ويكون له الفصل في معظم القرارات واله السياسات

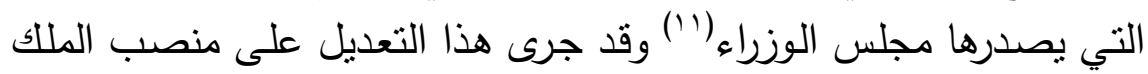




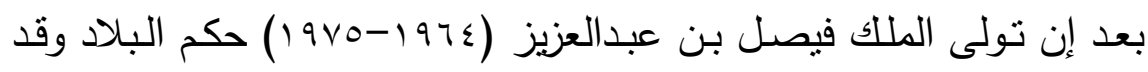

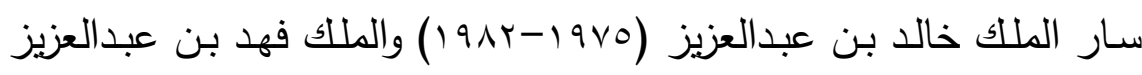

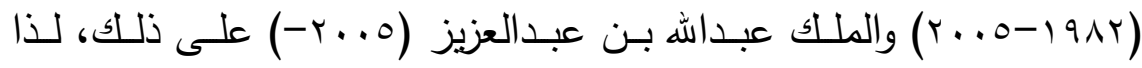
منصب الملك يجمع الرئيس الأعلى للاولة ورئيس مجلس الثورى الذي كان

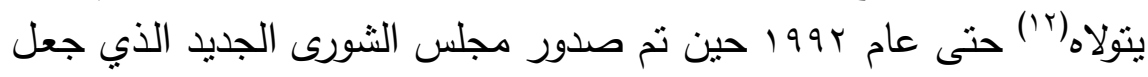
رئيس مجلس الثورى غير (الملك) على الرغم من اختيار الأخير لرئيس مجلس الثورى وأعضائه(r').

\section{ثانيا- مجلس الوزراء}

يعد مجلس الوزراء السلطة الرسمية التانية في التسلسل الهرمي للدولة بعد

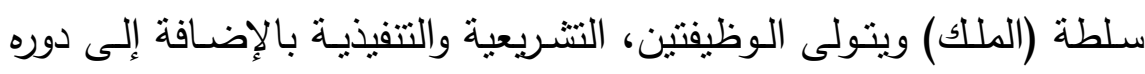
المهم في صنع القرار السياسي للمملكة العربيـة السـودية داخلياً وخارجياً وهو ما نصت عليه المادة (1) من نظام مجلس الوزراء لعام 1901 1، والتي والي

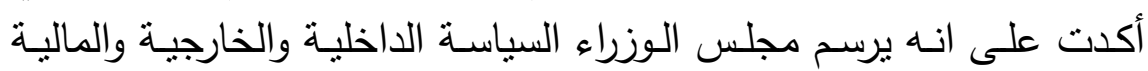

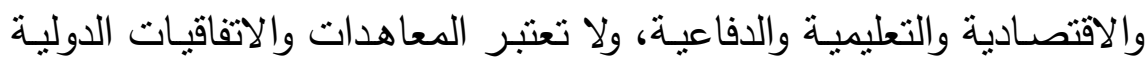

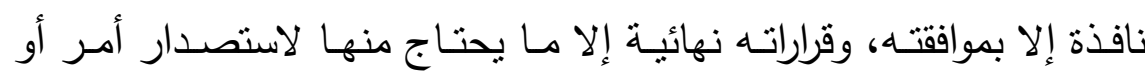

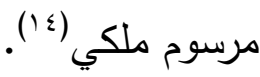

أصبح مجلس الوزراء من أقوى أجهزة النظام السياسي في المملكة إذ إن إنهام يتمتع بسلطات واسعة ويستمد قوته من خلال ارتباطه الوثيق بالملك بعدما

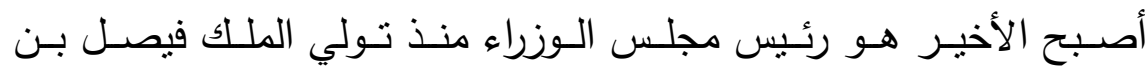
عبدالعزيز مقاليد الحكم واعتلائهـ العرش، وأصبح ولي العهد نائباً لرئيس مجلس الوزراء(10). سار على وفق هذا النهج الملك خالد والملك فهد الذي كرسـه في النظام

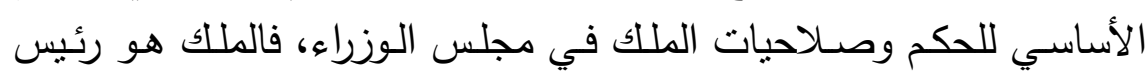

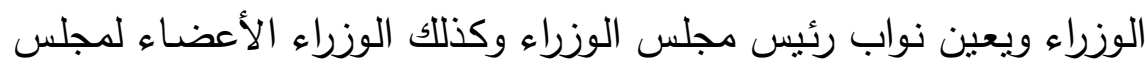


الوزراء ونواب الوزراء ومن هم في الدرجات الممتازة ويعفيهم من مناصبهر

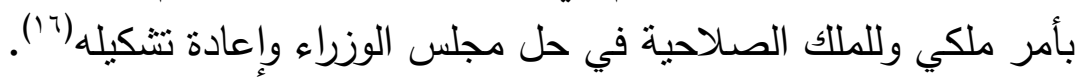

$$
\text { ثالثا- مجلس الثورى }
$$

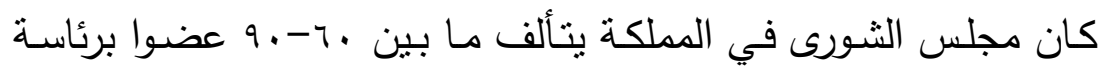

(الملك)، وهو لا يتعدى كونه مجلس ذا صفه استشارية يجري تعينه من قبل فيل فئل

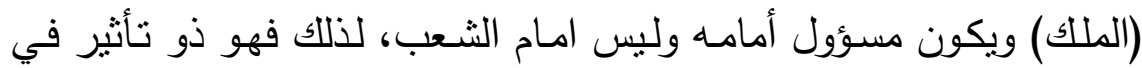

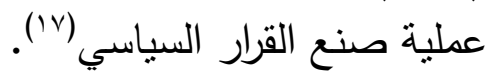

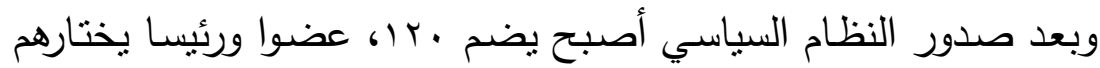

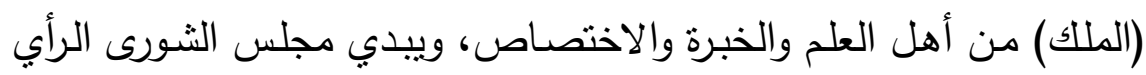

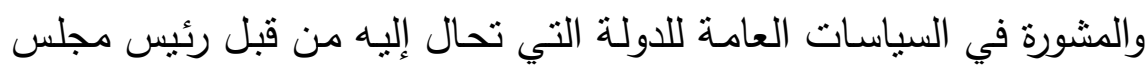

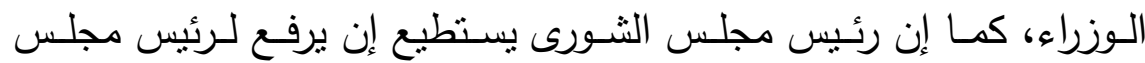

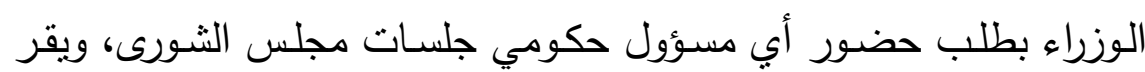

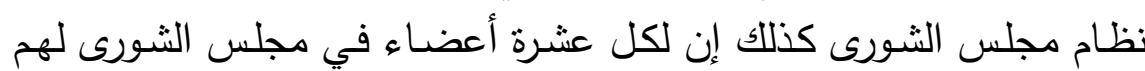

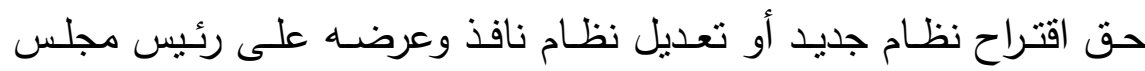

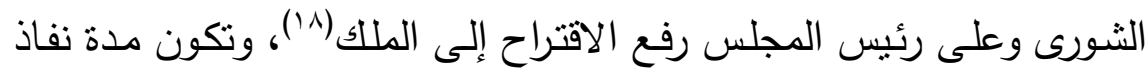

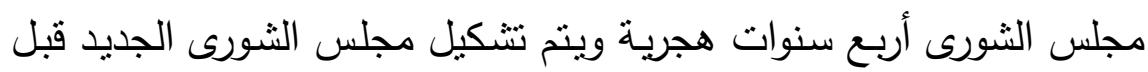

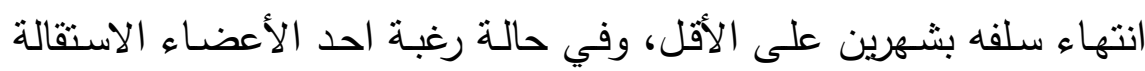

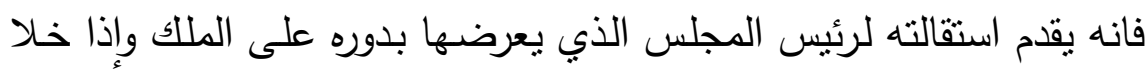

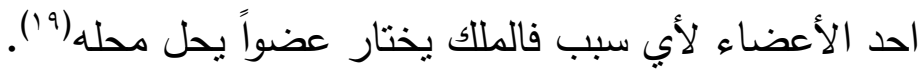

رابعاً- النظام القضائي تأخذ المملكة العربية السعودية بنظام تعدد جهات القضاء، فهناء القياك القضاء

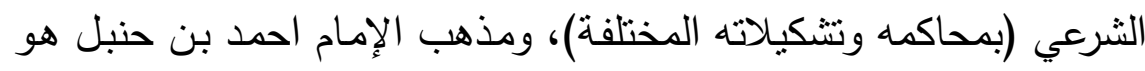


المذهب الرسمي في القضـاء في المملكةة(r)، وفيمـا يلي مؤسسـات النظـام القضائي:

\section{1ـ القضاء الثرعي}

هو المؤسسة الثرعية صاحبة الولاية العامة المسؤولة، بالنظر في جميع المنازعات التي تتشأ داخل المجتمع السعودي أياً كانت طبيعتها أو أطرافها، أما هيكل القضاء فهو : لمنازعات

أ- المحاكم العامة، والجزائية

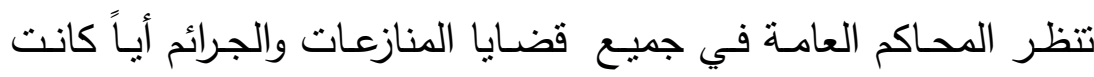
طبيعتها بعد استبعاد القضايا التي نكون من اختصاص المحاكم الجزائية(r) وتصدر أحكامها عن قاضي واحد، وتستثنى من ذلك قضايا القتل والرجم

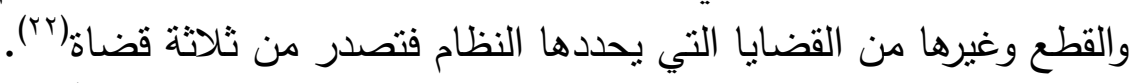

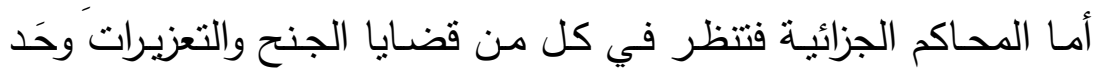
السُكر، وفي الجنايات التي لا تزيد عن خمس الدية(rآن. ب- محكمة التمييز تتكون محكمة التمبيز من رئيس وعدد محدد من القضاة. واختصت هذه

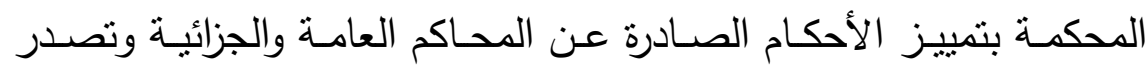

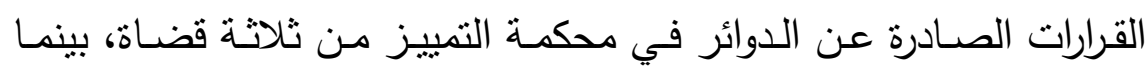

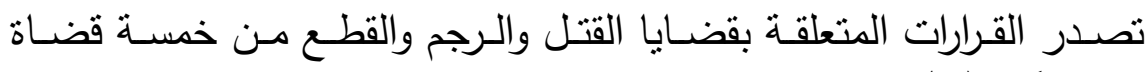

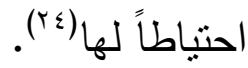

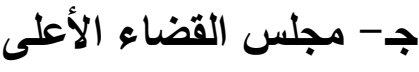

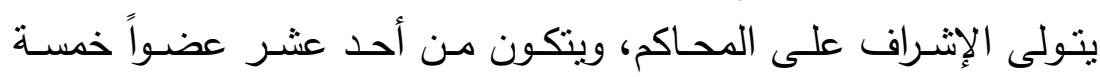

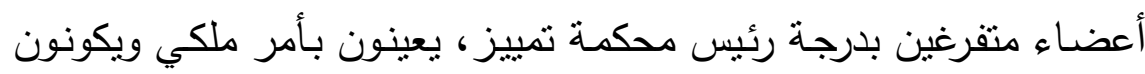

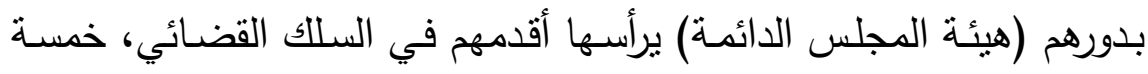


أعضاء غير متفرغين وهم رئيس محكمة التمييز أو نائبه ووكيل وزارة العدل

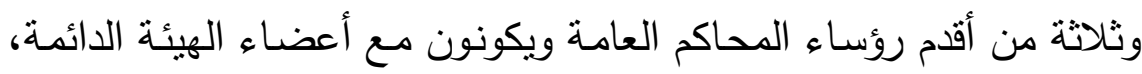

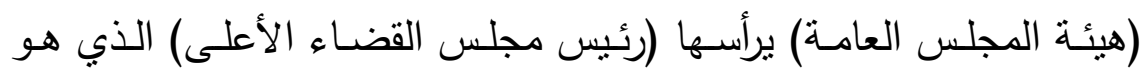

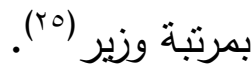

ويمـارس مجلس القضـاء مجموعـة مـن الاختصاصـات المختلفـة يمكن

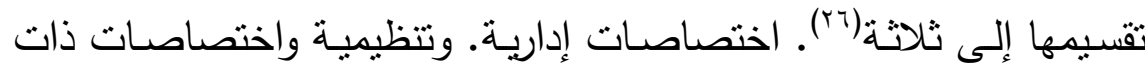
طبيعة قضائية خالصة.

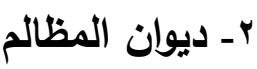
يعد سلطة قضـاء إداريـة مستقلة ترتبط مباشرة بشخص الملك ورئيسـه،

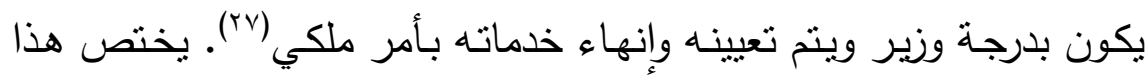

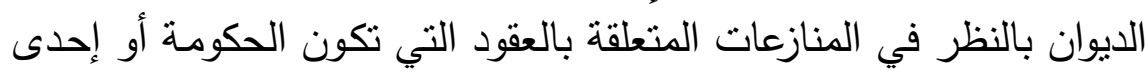

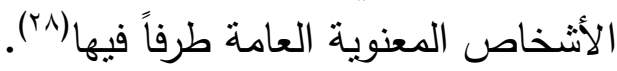
r- اللجان الإدارية ذات الاختصاص القضائي تضم المؤسسة القضائية العديد من اللجان الإدارية والهيئات التي تمارس

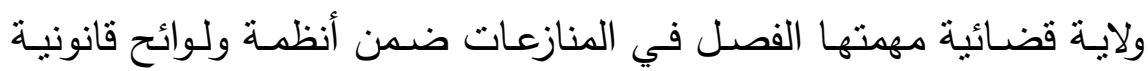

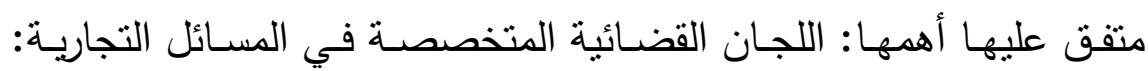

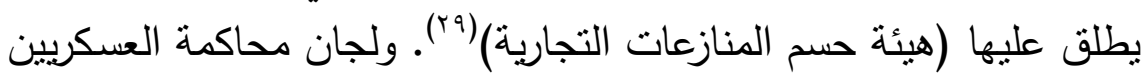

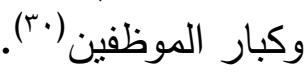

\section{خامساً - المؤسسة الدينية}

ترتبط المؤسسة الدينية بعدة هيئات، أبرزها هيئة كبار العلماء والرئاسـة

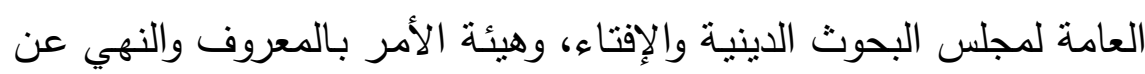


المنكر وهذه الهيئات تشكل مجتمعة المؤسسة الدينية الرسمية المستقلة عن

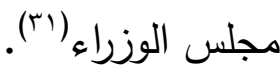

\section{1- - ميئة كبار العلماء}

تتألف هيئة كبار العلماء، من عدد من العلمـاء المختصين في الثربعة

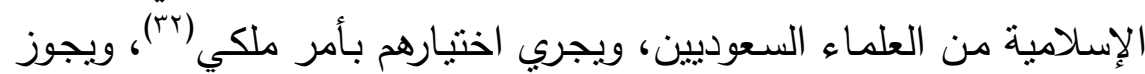

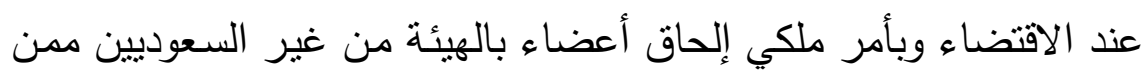

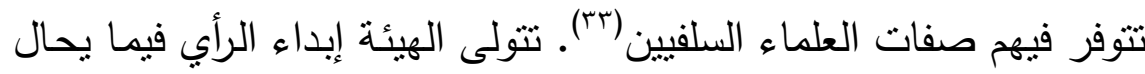
إليها من (الملك) والحكومة من أجل بحثه، وتكوين الرأي المستتد إلى الأدلة الثرعية فيه، كما تقوم بالتوصية في القضايا الدينية المتعلقة بتقرير أحكام عامة؛ تنترشد بها الحكومة، وذلك بناء على بحوث يجرى تهيئتها وإعدادها

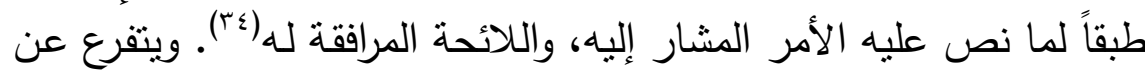

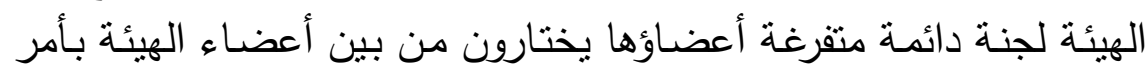

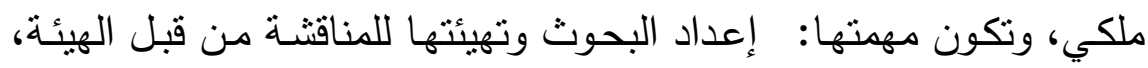
وإصدار الفتاوى في الثؤون الفردية، وذلك بالإجابة عن أسئلة المستفنين في

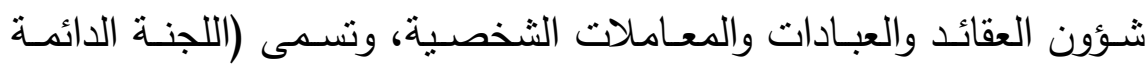
للبحوث والفتوى) ويلحق بها عدد من مراكز البحوث(ب0.

\section{r - الرئاسة العامة لإدارة البحوث الاينية والإفتاء}

تعد رئاسة هذه الهيئة بمثابة القيادة الفعلية داخل المؤسسة الدينية ،إذأ أنها

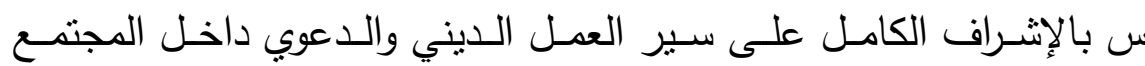

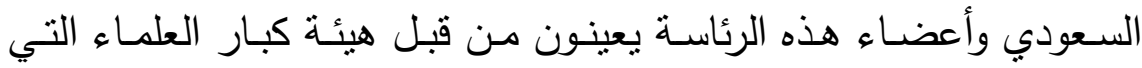
تختارهم من بين العلماء والبارزين والمعروفين والمشهود لهم علمياً، ولأهمية

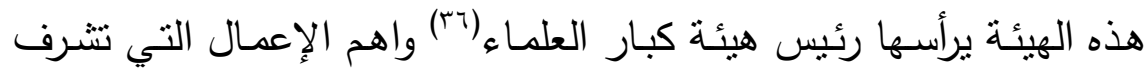
عليها هـي: تحديد مصدر الفتاوى في المملكة، وتحديد شكل ومحتويـات 
المناهج الدراسية في المدارس والجامعات لتكون منسجمة مـع الخط الرسمي

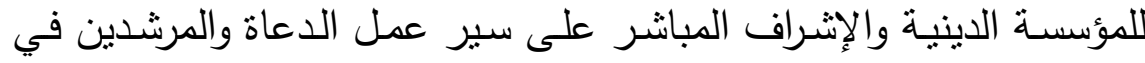

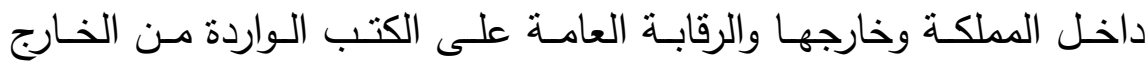

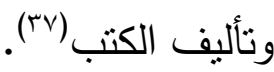

\section{r- هيئة الأمر بالمعروف والنهي عن المنكر}

لهذه الهيئة مهام مباشـرة تترجم في وقهع المجتمـع السـعودي في عـدة

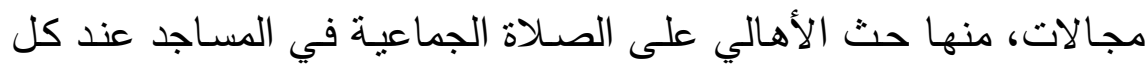
أذان لذلك تغلق المحال التجارية في الأسواق أو تترك دون وجود احد للبيع

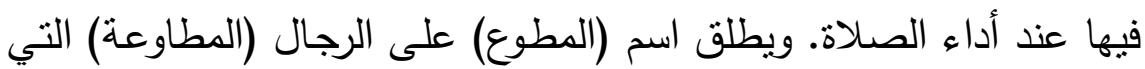

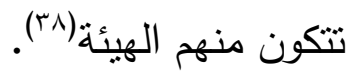
وفي مواسم الحج والعمرة تكون مهام المطاوعة تعليم الحجاج والمعتمرين

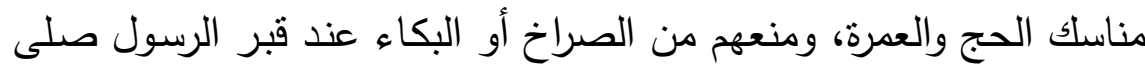
الله عليـه وسـلم ومحاولـة التشـبث أو ملامسـة القبـر ـ وغيرهـا مـن الإعمـال

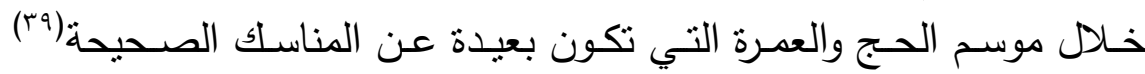
وللمطاوعة واجبات أخرى اجتماعية في الأسواق والساحات العامة من اجل

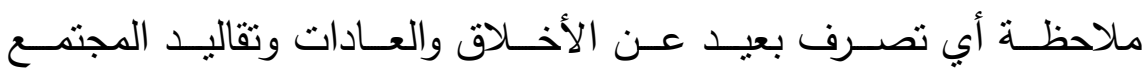

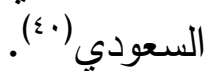

ثانياً: النظام السياسي في الجمهورية الإسدلامية في إيران بعد نجاح الثورة الإيرانية، شهدت إيران حراكات فكرية بين ابرز التيارات

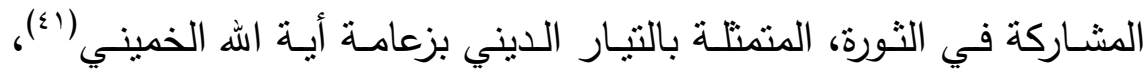

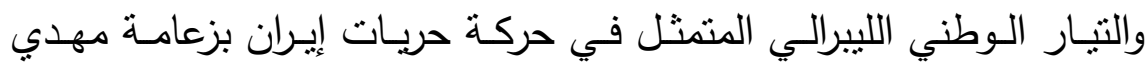


بازركان والجبهة الوطنية بزعامـة كريم سنجابي، والتيار اليساري الذي يعد

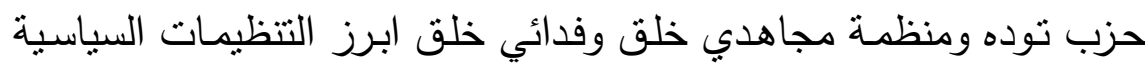

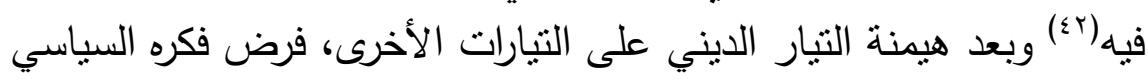

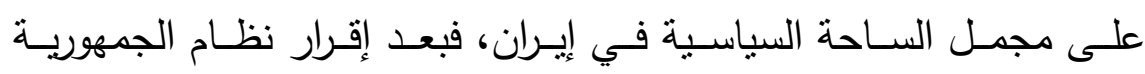

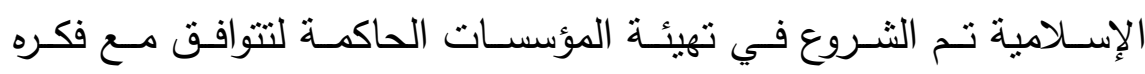

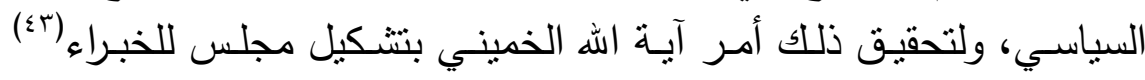

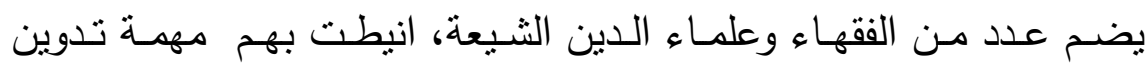
الدستور، وقد اعتمد مجلس الخبراء في تدوين الدستور على عاملين أساسين لتعزيز مكانـة وصـلاحيات الولي الفقيه، ومراعاة تطبيق القوانين والإحكام الإسلامية، إلى جانب تأسيس مؤسسات تهتم بكل ما هو أسـامي في نطاق ونات

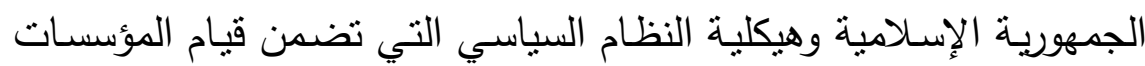
الآثية:

\section{أولا: المرشد الأعلى}

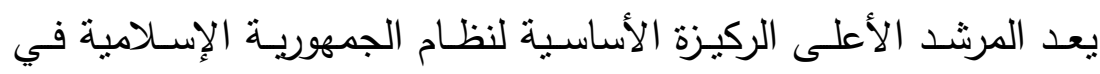

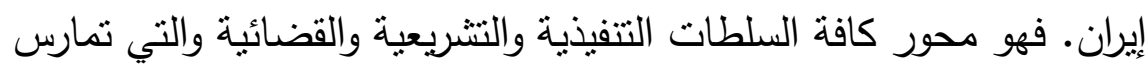

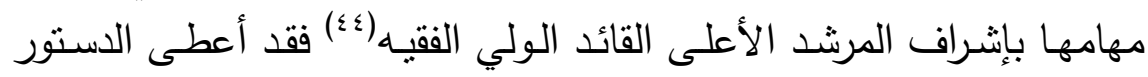

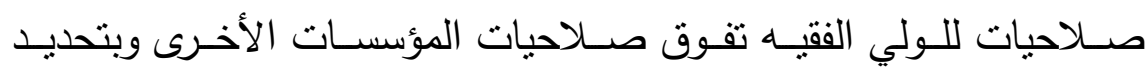

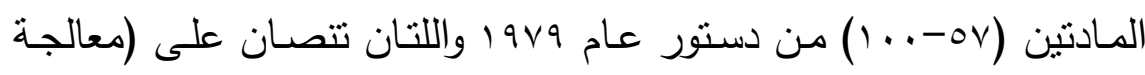

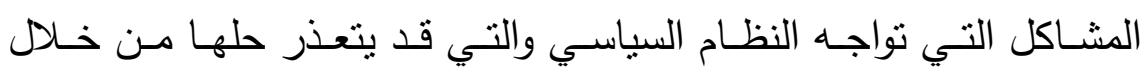

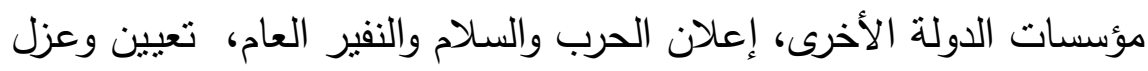
كل من فقهاء مجلس صيانة الدستور، أعلى مسؤول في السلطة القضائية،

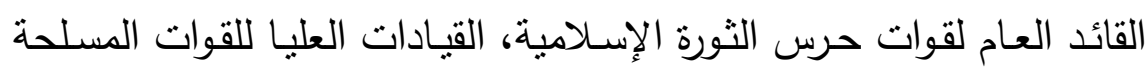
وقوى الأمن الداخلي، إقرار تتصيب رئيس الجمهوريـة، بعد إن تتم عملية

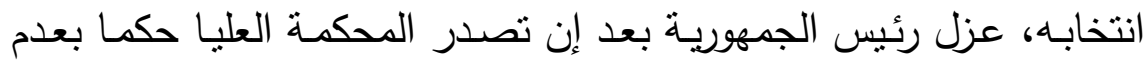


التزامه بأداء واجباته ووظائفه القانونية أو بعد بيان مجلس الثورى (العفو أو التخفيف من عقوبات المحكوم عليهم)(؛ §).

وبعد إجراء تعديل الدستور عام 19 أزادت صلاحيات المرشد فشملت

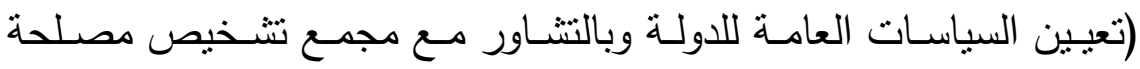
النظام والإشـراف على تتفيذ سياسـة الدولة، وإصدار أمر بإجراء الاستفتاء

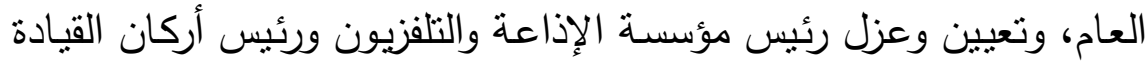
المشتركة، ومعالجة الخلافات التي قد تتشا بين السلطات الثنلاث (التشريعية والقضائية والتنفيذية) فضلا عن تتظيم العلاقات بينهم (T؛) وبحكم شغل أية

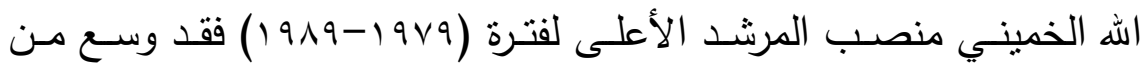

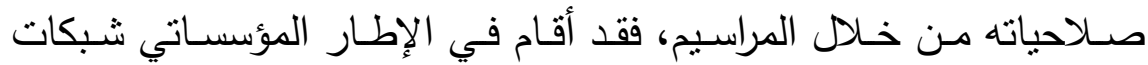
شخصية متذاخلة، إذ فرض سلطته على أصحاب المناصب الرسمية العامة في الدولة عن طريق تعيين ممثليه الثخصيين ويعرفون باسم ممتلي الإمام

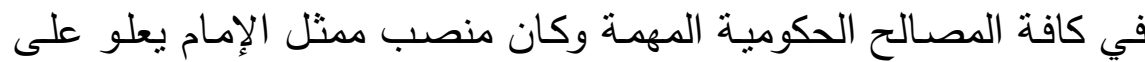

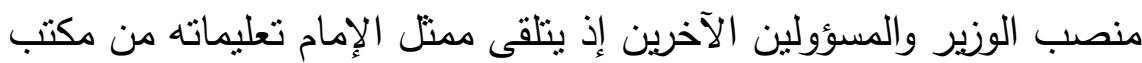

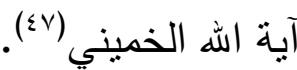

إما فيما يخص تعيين المرشد الأعلى فتتم من قبل مجلس خبراء القيادة

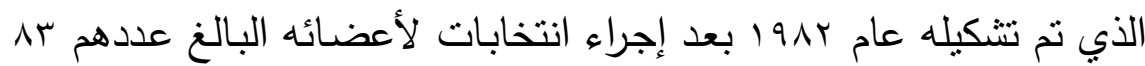
عضـوا ومعظمهم مـن (مجتهدين) و (علمـاء الحـوزة العلميـة) وتكون دورة المجلس ثمان سنوات(^؛) وكان هدف هذا المجلس هو ترشيح خليفة للخميني لتولي منصب المرشد بعد وفاته(9) وقد تم أقرار هذا المجلس في التعديل

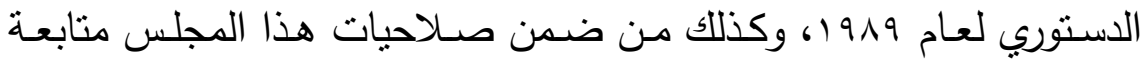

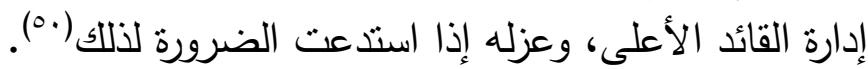


نص دستور عام 9 199 على تشكيل سلطة تتفيذية يكون على رأسها

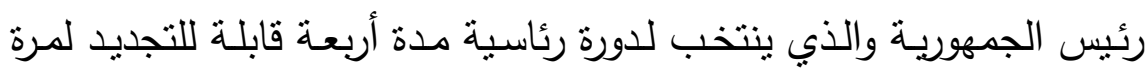

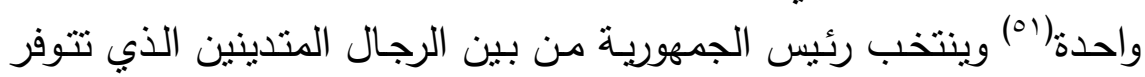

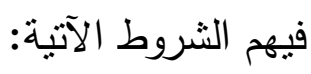
أن يكون إيراني الأصل ويحمل الجنسية الإيرانية، وان يكون له القدرة في

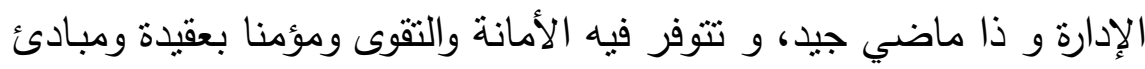

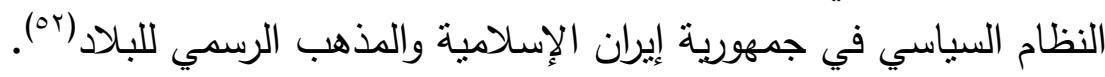

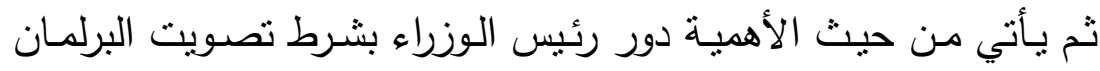

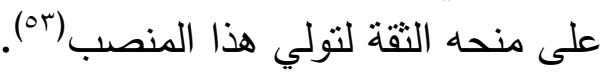

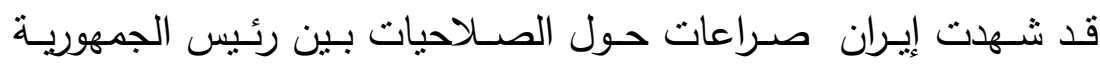
ورئيس الوزراء، لاسيما حول الصلاحيات المخولة لرئيس الجمهورية، فعندما لئان

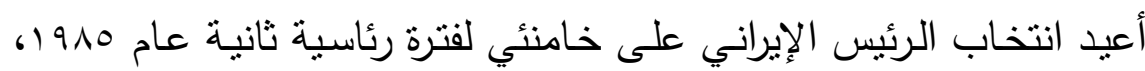

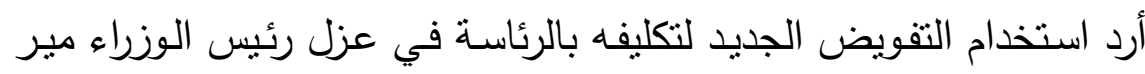

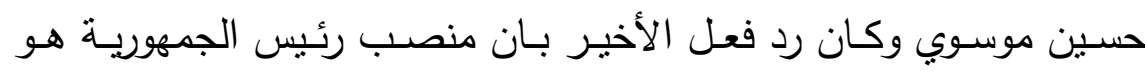

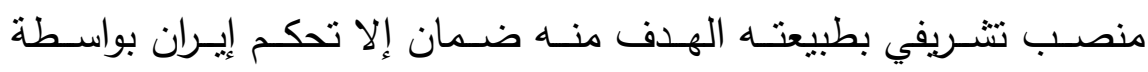

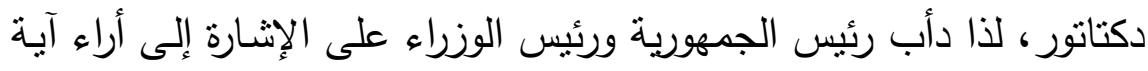

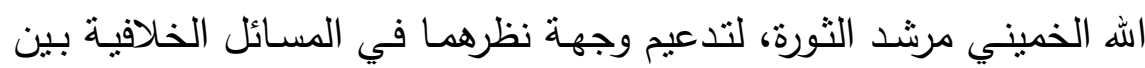
المؤسستين (0٪)

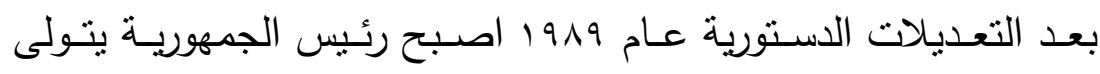

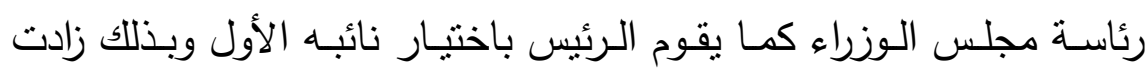

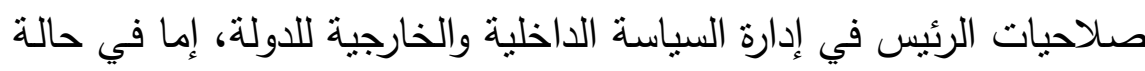

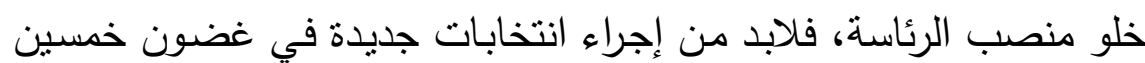

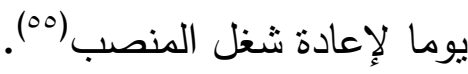

ثالثا: السلطة التشريعية 
انبتقت السلطة النتريعية في إيران وفق ما ورد في دستور عام 9v9

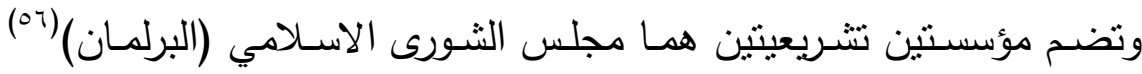
ومجلس صبانة الدستور •

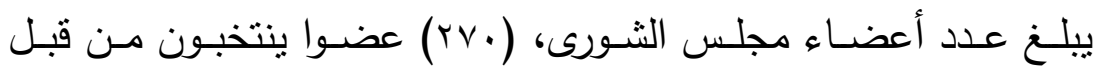
الشعب لمدة أربع سنوات ويمكن زيادة عشرين عضوا كحد أقصى كل عثر

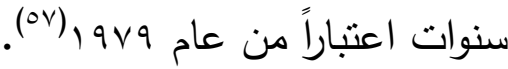
وينص الدستور الايراني على إن أعضـاء المجلس هـ مـ من المسـلمين

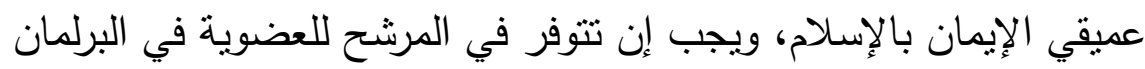

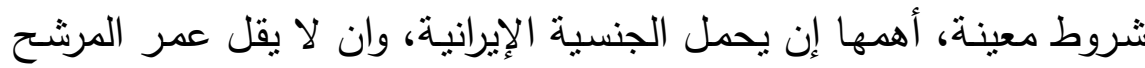

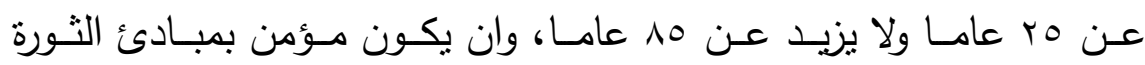

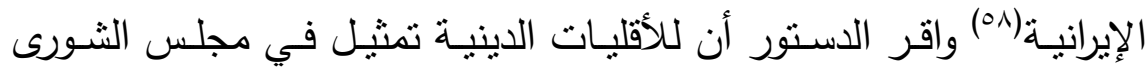
بحسب كثافتهم العددية حيث يوجد ممثل لإتباع كل من ديانات النصرانية واليهودية والزرادشتية(ه9). وقد اقر الدستور الفصل بين مهام وصلاحيات مجلس الثورى في مواده

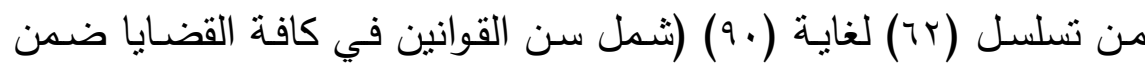
الحدود المقررة دستوريا، وشرح القوانين العادية والتدقيق والتحقيق في كافة

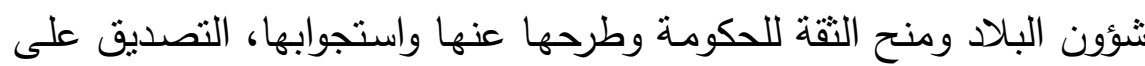
المواثيق والعقود والمعاهدات والاتفاقات الدولية)(· (7).

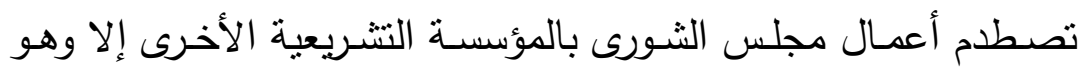

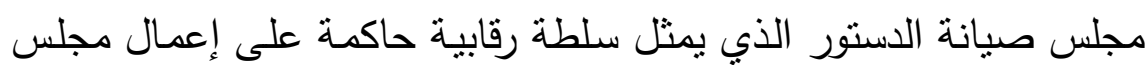
الثورى وممارسته (1). يتكون مجلس صبانة الدستور من r ا عضوا 7 منهم من المجتهدين من ون علماء الحوزة يعينهم المرشد والذي يوقع على تعيين 17 آخرين من حقوقيين وخبراء قانون ينتخبهم مجلس الشورى من قائمة يتم ترشيحهم من قبل فئل رئيس

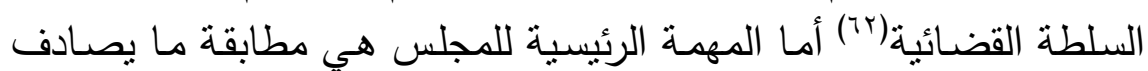


عليه مجلس الثورى مـع الإحكام الإسـلامية والدستورية(rآ) والمجلس رقابي

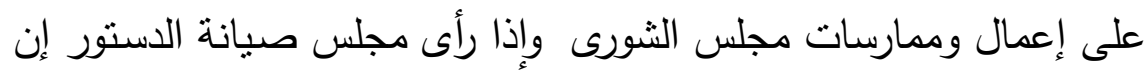

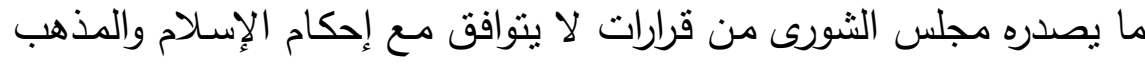
الرسمي في البلاد فانه يقوم باعدتها إلبه، كما أن المجلس هو هورات الجهة الوحئ الوحيدة المؤهلة لتفسير مبادئ الدستور (؟؟7). وبسبب التعارض بين قسمي السلطة التشربعية شكل أية الله الخميني في 17 شباط 1911 هيئة سياسية سميت بمجمع تشخيص مصلحة النظام وقد أعطي لهذه الهيئة سلطة اتخاذ القرار النهائي في المسائل المتتازع عليها بين مجلس الشورى ومجلس صيانة الدستور (70). وشـرع تشـكيل مجمـع تشـخيص مصـلحة النظـام في الدسـتور الإيراني

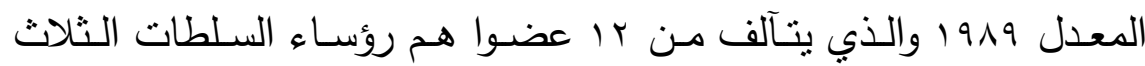

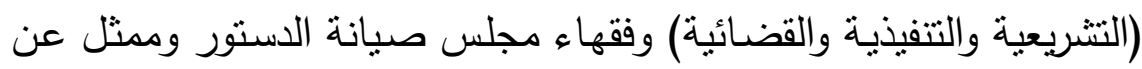

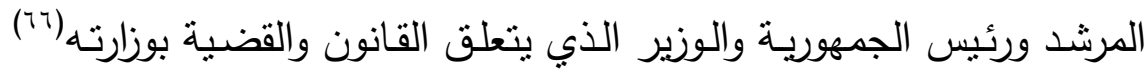

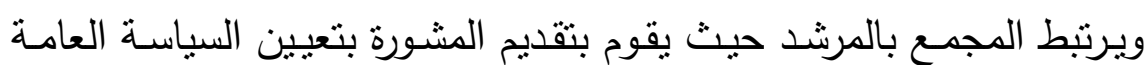
للاولة (TV)

\section{رابعاً: السلطة القضائية}

جاء في مقدمة الدستور الإيراني التأكيد على عقائدية القضاء، واعتبر أن أنهاء النهاء

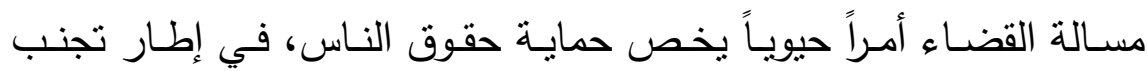

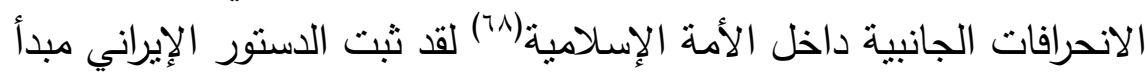

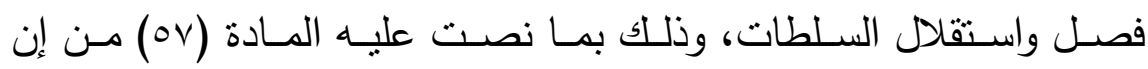

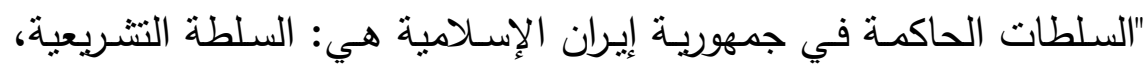
والسلطة التتفيذية والسلطة القضائية، وتمارس صلاحيتها بإنراف ولي الأمر اليران

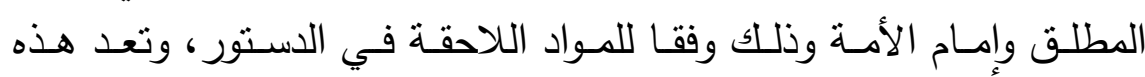


السلطات مستقلة عن بعضها(79) تباشر السلطة القضائية إعمالها من خلال هيكلها الإداري والتطبيقي ويترأسـها شخصـا عـادلا مجتهـدا ملمـا بـالأمور القضائية يتم اختياره من قبل الرشد الاعلى، وبيتمر رئيس السلطة القضائية

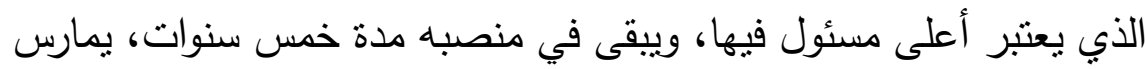
رئيس السلطة القضـائية مهمـة إعداد اللوائح القضـائية المتتاسبة مـع نظـام

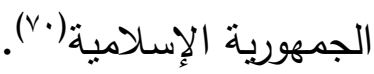

إما فيما يخص وزير العدل فيأني في سلطنه الإدارية بعد رئيس السلطة

القضائية الذي يتولى الإشراف على تشكيل المحكمة العليا للبلاد (محكمة

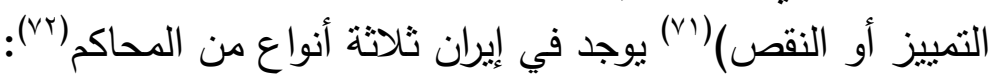
النـوع الأول: المحاكم العامـة وهي التي تتظر في كافة القضــايا باسـتثناء القضايا التي تقع ضمن اختصاص المحاكم الثورية أو الخاصة. النوع الثاني: هي المحاكم الثورية التي نتظر في:

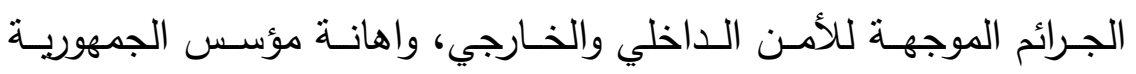
الإسلامية الإمام الخميني، أو النقد لأداء المرشند. التآمر ضـد النظام وممارسـة التخربب ضـده، التجسس، تهريب الإمب المخدرات

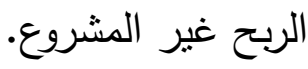
النوع الثالث: هي المحاكم الخاصة، منل الأسرة التي نص الدستور الإيراني على تشكيلها (Vrr) بهدف الحفاظ على كيان الأسرة واستمرار بقائها، والمحكمة الإنة العسكرية التي تتظر في القضايا العسكرية والأمنية التي تهم إفراد الجيش ولئي والأجهزة الأمنية، والمحكمة الصحنية الخاصة بقضايا الصحابة والمطبوعات أما محكمة علماء الدين فإنها مختصة بالنظر في القضايا الآتية:

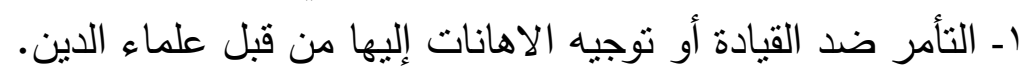
r- كافة الإعمال والتصرفات غير الثرعية التي يرتنكبها علماء الدين. 
זـ كافة المنازعات المحلية المخالفة للأمن العام التي يكون احد الخصوم

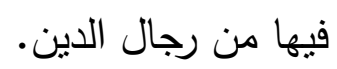

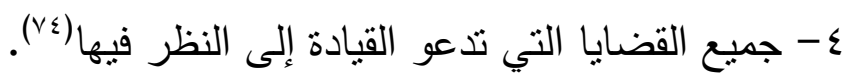

خامسا: المؤسسة الدينية

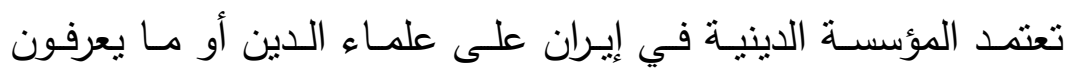

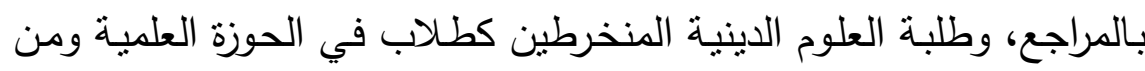

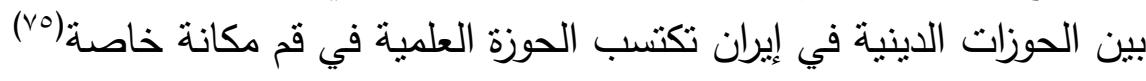

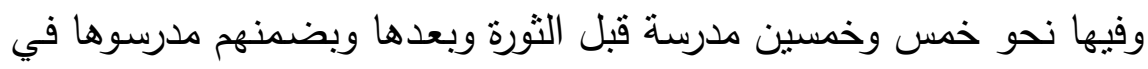

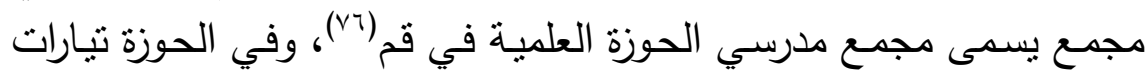
ومواقف ومذاهب سياسية كثيرة تزهو وتتفاخر بالاستقلال ومواجهة بعضئه فئها

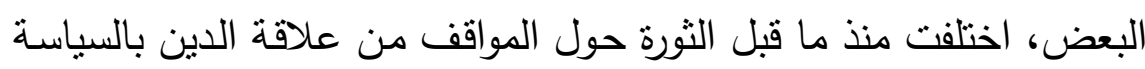

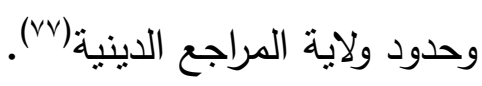

تحولت المؤسسة الدينية في إيران بعد نجاح الثورة وتقنيين ولاية الفقيه في

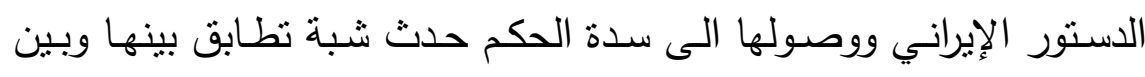
أجهزة الدولة. ومن أهم أجهزة المؤسسة الدينية المرتبطة بالولي الفقيه هي:

- الأمانة الائمة لائمة الجمعة والجماعات

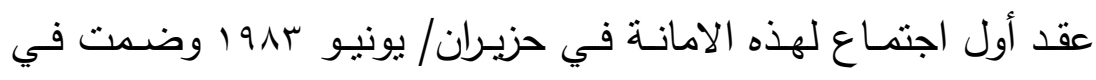

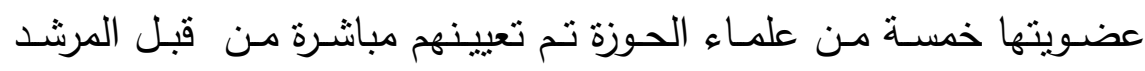

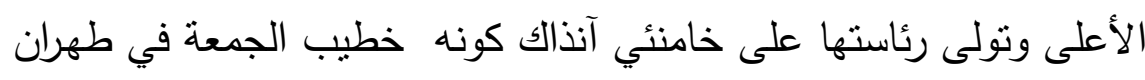

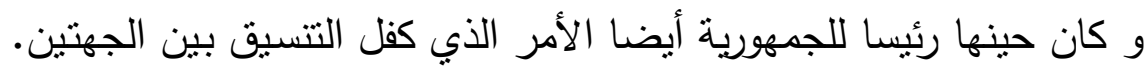

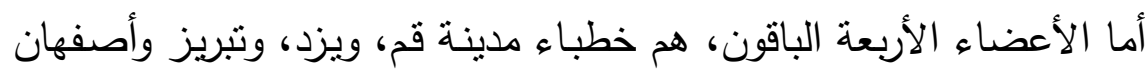

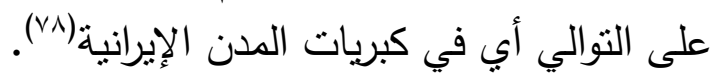




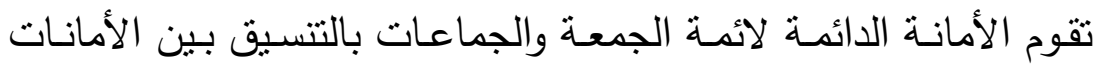

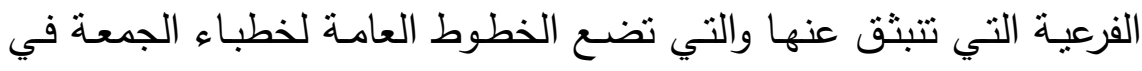
مختلف البلاد. كما تتصل الأمانة بالتتظيمات التي يولفها علماء الدين داخل

إيران وخارجها، وتتظم مؤتمرات لائمة الجمعة ونتولى تتفيذ توصياتها (V9).

- هيئة الأمر بالمعروف والنهي عن المنكر

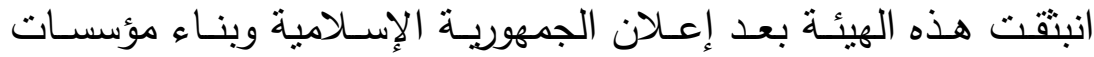
الدولة، وهذه الهيئة تمثل الثرطة الدينية في المجتمع الإيراني، ولها العديد من المهام منها فرض الحجاب على النساء الإيرانيات(.^).

الخاتمة

هنالك العديد مـن نقاط النشـابه بين كل من النظام السياسي في ايران والنظام السياسي في المملكة العربية السعودية :

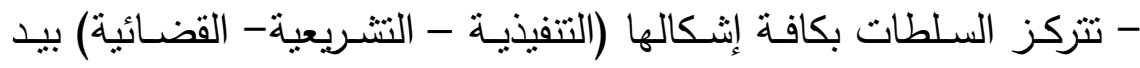
شخص واحد هو الولي الفقيه المرشد الأعلى وهو منصب لا يوجد إلا

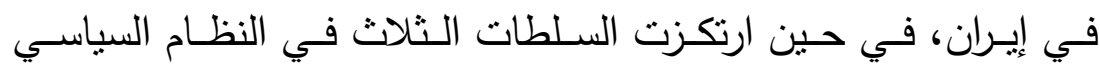
السعودي بيد الملك الذي يتولوه الإخوة من أبناء عبد العزيز حسب ترتيب التبري أعمارهم، لذلك فهو يتميز عن بقية الأنظمة الملكية.

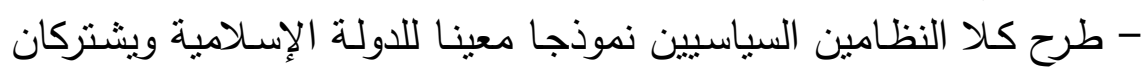
في تمسكهما بالقيم الإسلامية العامة وفي كون الثريعة الإسلامية القانون الأساسي للاولة ويقوم علمـاء الدين في كلا البلدين في تتظيم المجتمع الإنه

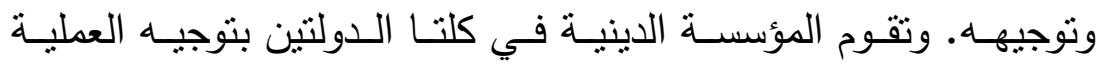
التعليميـة، كمـا تقوم وتؤكد الثـرطة الدينيـة في كلا البلدين على التزام 


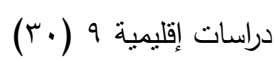

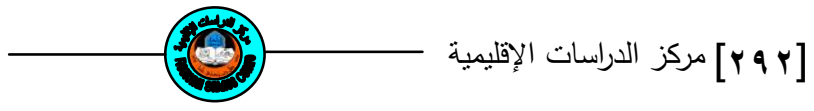

الكامل بأمر الثربعة وحرفية نصوصها حسب فقه المذهب الرسمي لكلا

الدولتين.

وبينما بسيطر آيات الله على معظم الوزارات والمؤسسات الحكوميـة في

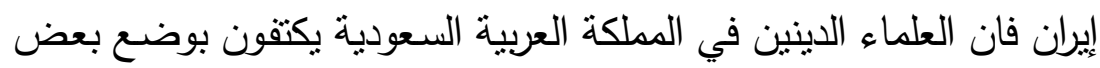

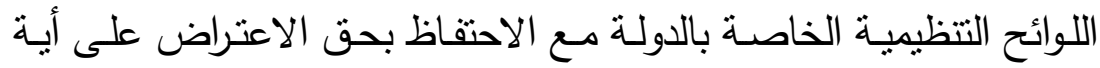

تشريعات يرون أنها تتنافى مع مبادئ الثريعة الإسلامية.

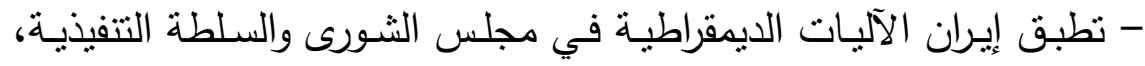

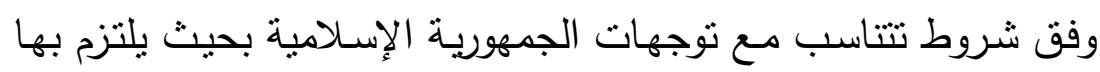

المرشـحون، بينمـا في المملكة العربيـة السـعودية فـان للملك حق فق القيـام

بإصدار المراسيم ملكية بتعين مجلس الشورى والوزراء في مجلس الوزراء

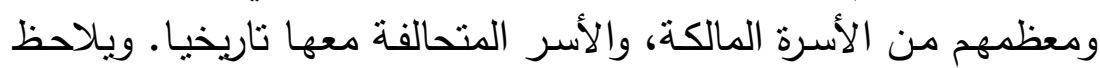

أن لهذا التشابه في طبيعة النظام السياسي لكالا البلدين الأثر في تحديد

شكل العلاقات بينهما.

\title{
The political system in Saudi Arabia and the Islamic A Republic of Iran Comparative View
}

\section{By Mr. Abdalrazaq KH. Mohammed}

\begin{abstract}
Different from the monarchy in Saudi Arabia for the rest of the monarchies in the world, as different from the Islamic Republic of Iran from the rest of republican regimes in the world, concentrated authorities in all its forms (executive-legislative-judicial), however, one person is the guardian jurist Supreme Leader, a position that there is only in Iran, while based three authorities in the Saudi political system, however, the king, who Atoloh brothers, sons of Abdul Aziz, in order of age, so it is distinct from the rest of the monarchies, and
\end{abstract}


acquires the regimes paramount importance and therefore the position of the religious establishment in both countries.

\section{الهوامش}

(1) جون س ولينكسون، حدود الجزيرة العربية: قصة الدور البريطاني في رسم الحدود في الصحراء،

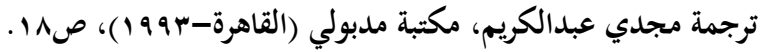

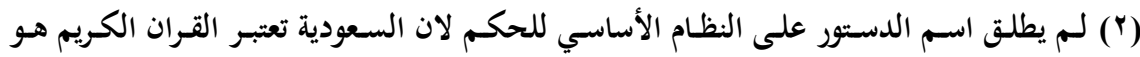

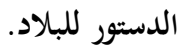

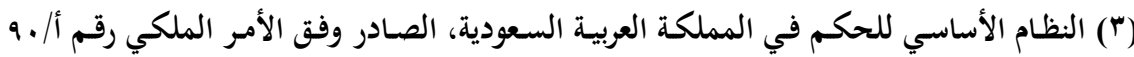

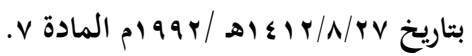

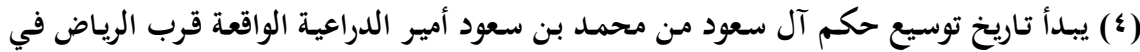

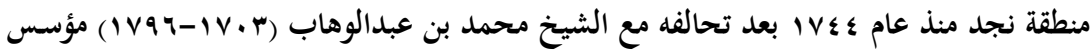
حركة الإصلاح الديني المعروفة بالوهابية التي تدعو إلى تطبيق تعاليم الإسلام على أساس نها نها

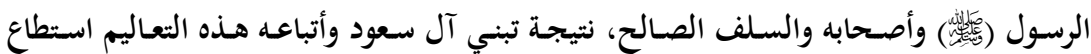

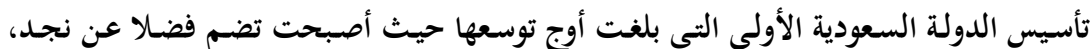

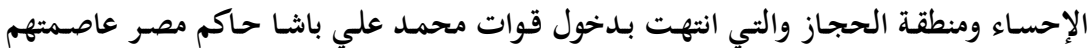

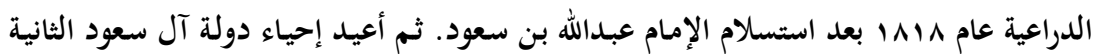

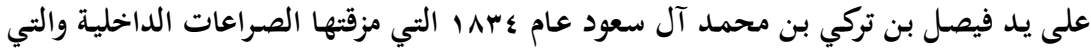

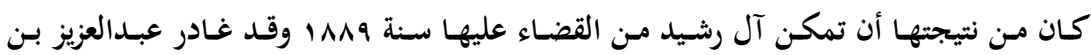

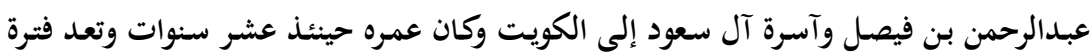

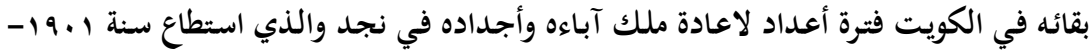

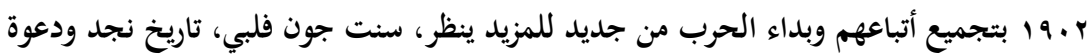

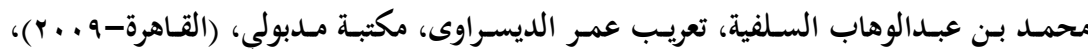

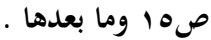

(0) محمد سعيد ادريس، النظام الإقليمي للخليج العبب، مركز دراسات الوحدة العبية، (بيروت-

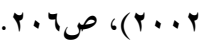

(1) الان غريش ودمونيك فيدل، الخليج مفاتيح لفهم حرب معلنه، ترجمة إبراهيم الويس، دار قرطبة

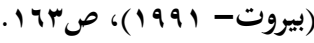


تقدر أعداد عائلة آل الشيخ با أكثر من إلف شخص، دون النساء وتنكون من أربعة فروع، ذرية

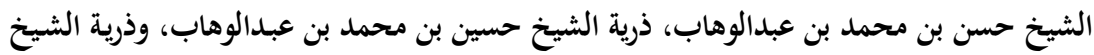

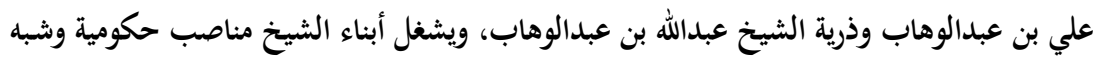

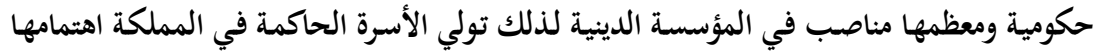

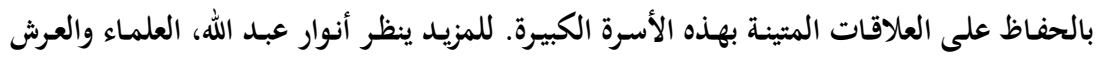

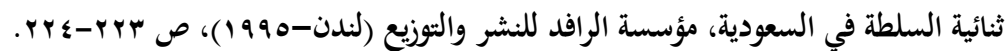

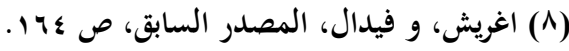

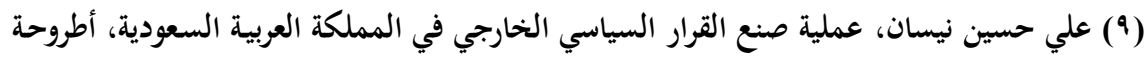

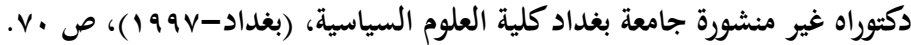

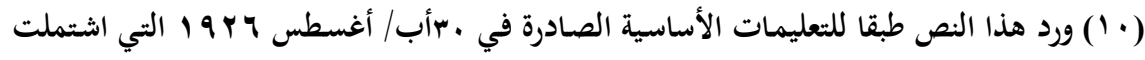

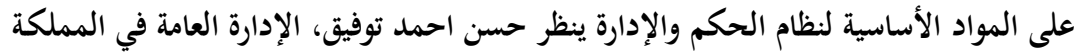

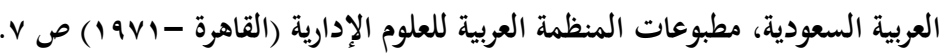

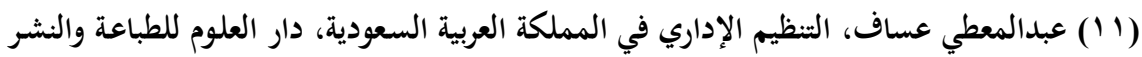

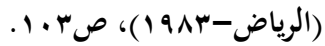

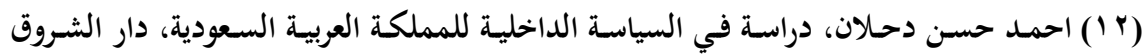

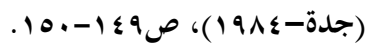

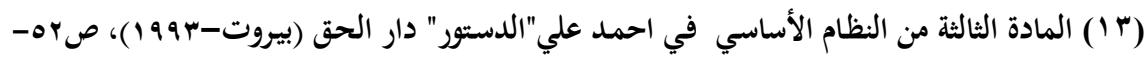

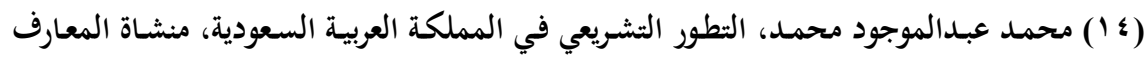

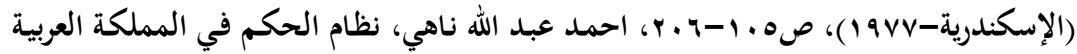

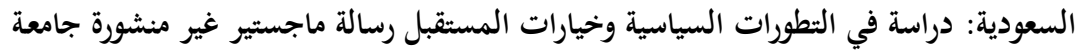

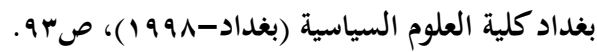
(0 1 ) محمد بن صنينان، النخب السعودية، دراسة في التحولات والإخفاقات، مركز دراسات الوحدة

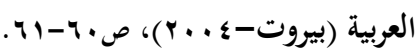

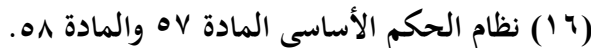

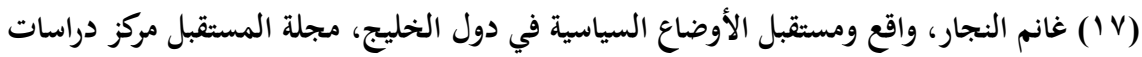

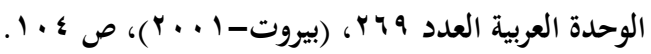


(1) وحيد حمزة هاشم، نظام الحكم في المملكة العربية السعودية، مكتبة دار جدة (جدة-ـ 9 9 ( ) صTri

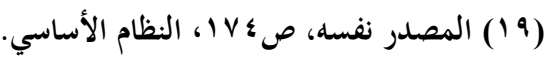

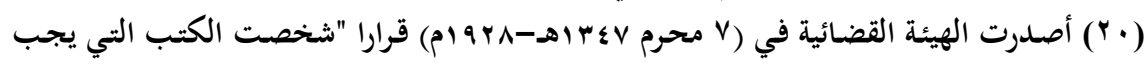

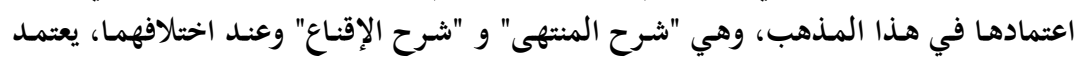

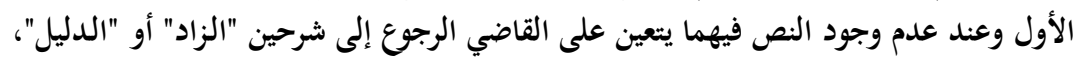

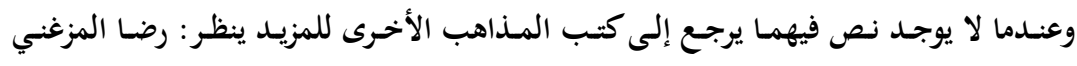

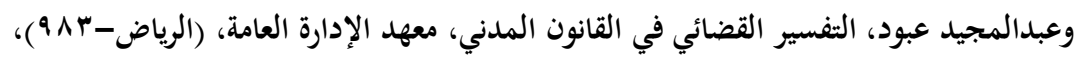

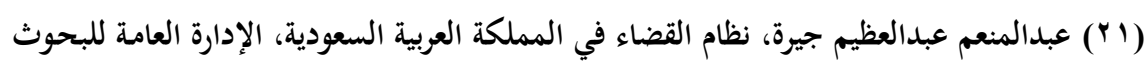

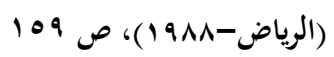

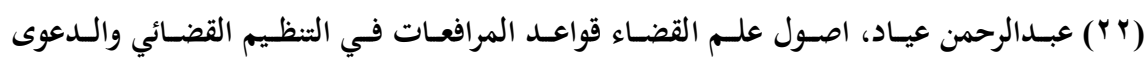

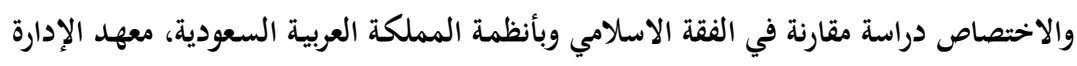

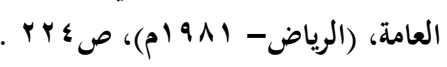

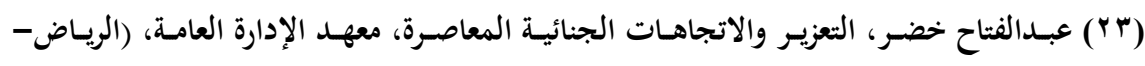

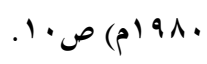

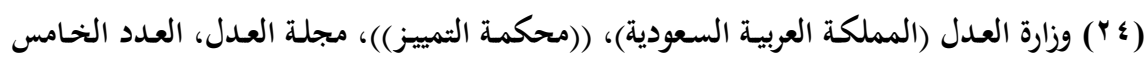

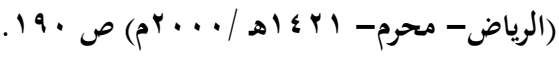

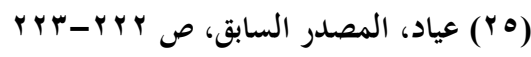

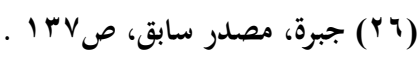

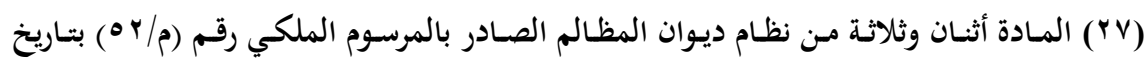

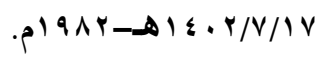

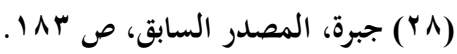

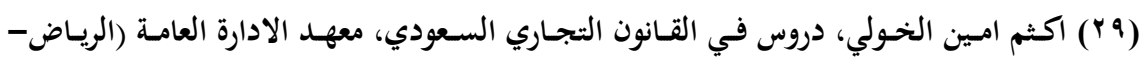

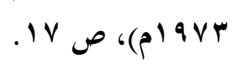

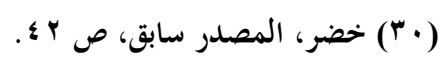


(آl) هناك مؤسسات ذات اهتمامات دينية مرتبطة بمجلس الوزراء مثل وزارة الحج والعمرة ووزارة

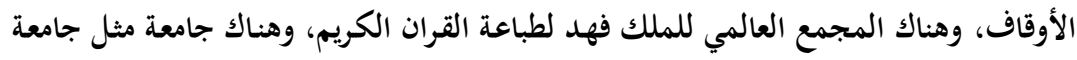

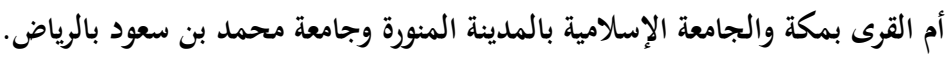

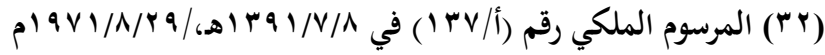

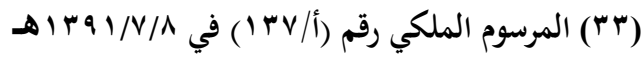

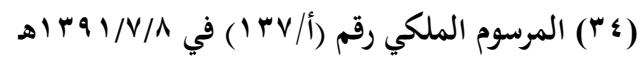

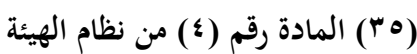

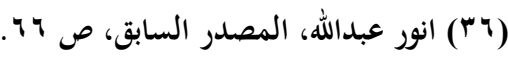

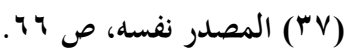

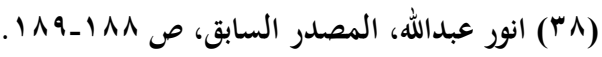

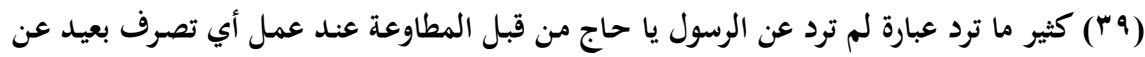

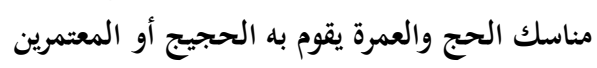

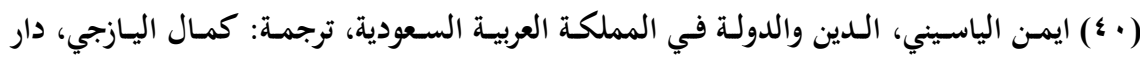

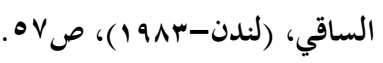

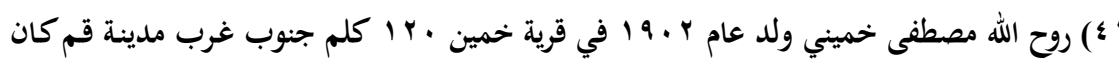

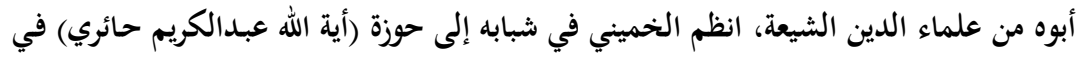

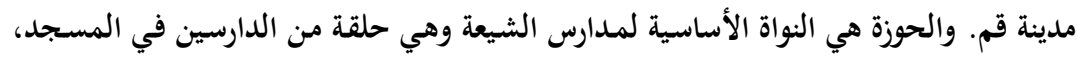

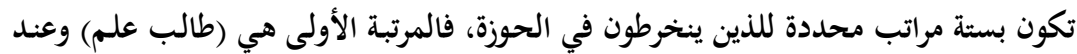

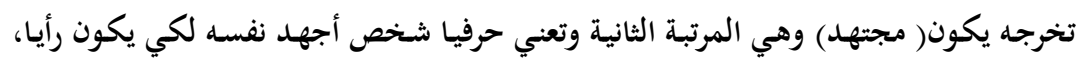

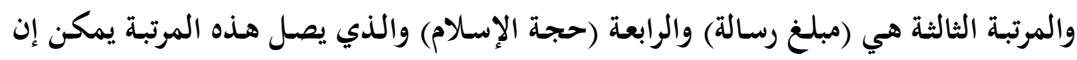

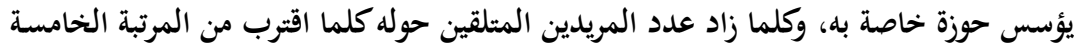

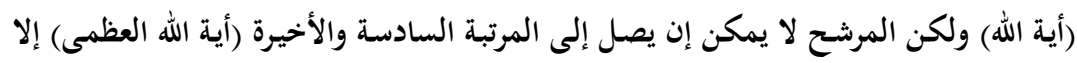

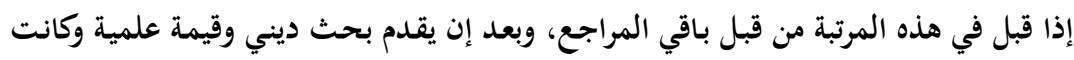

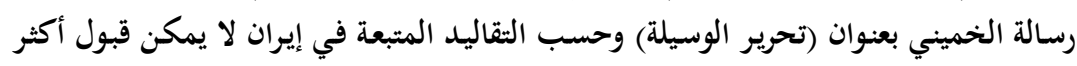

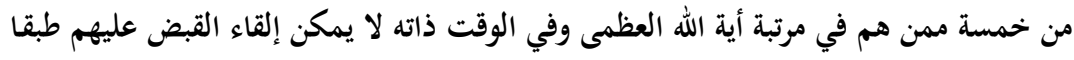

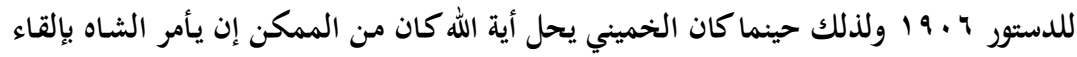

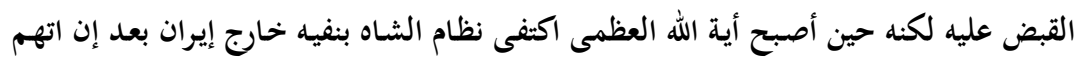

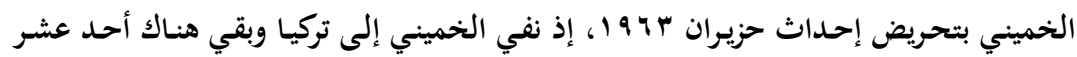




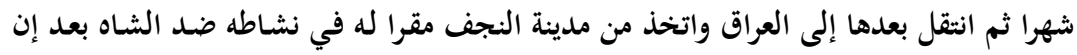

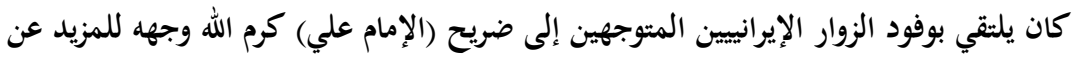

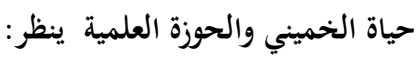

Hossein Musavian , Imam Khomeini : His Live and Leadership (London_1990);

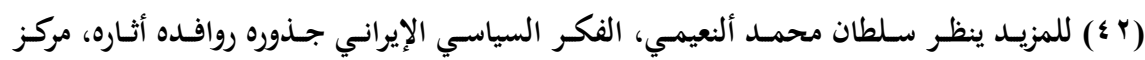

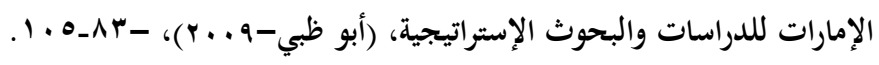

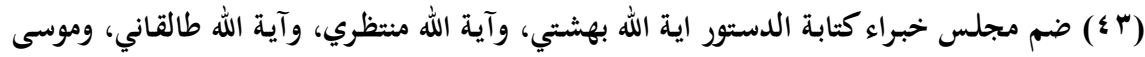

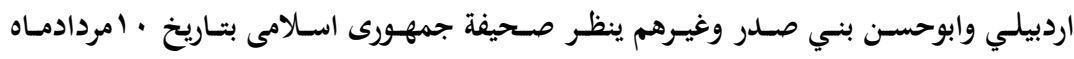

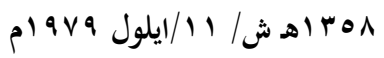

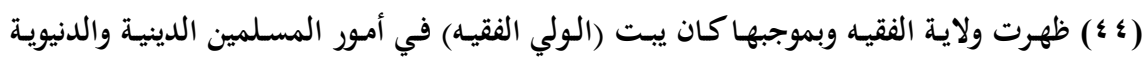

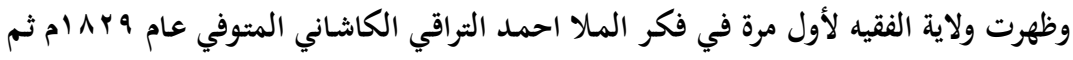

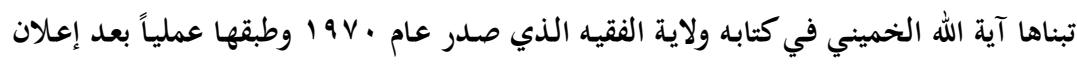

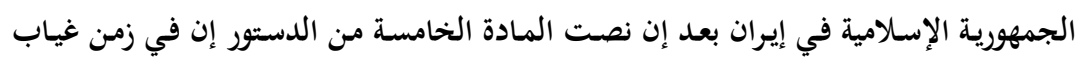

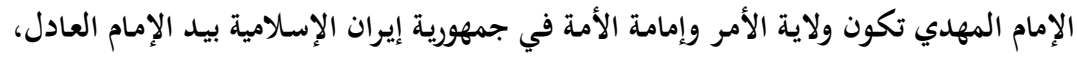

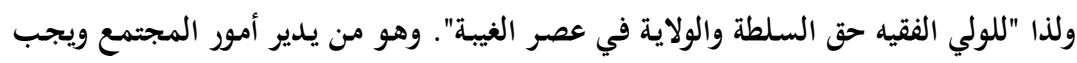

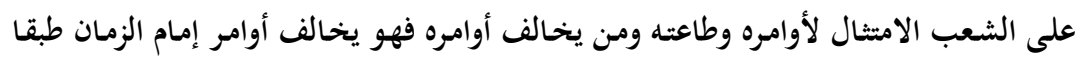

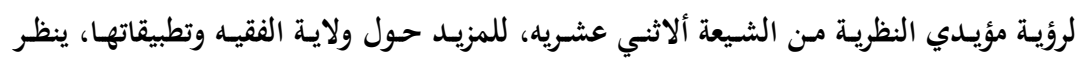

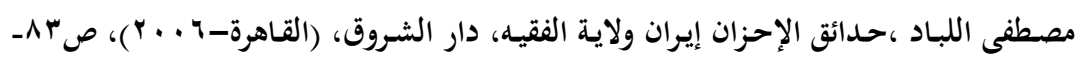

(0 ؛ خليل خليليان، نكرش بر قانون أسـاس جمهوري إسلام إيران، وقد نشر فرهنكك إسلامي

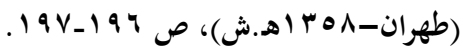

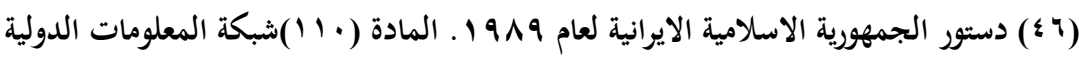

http// www.uuwab.com.

(؛ V)

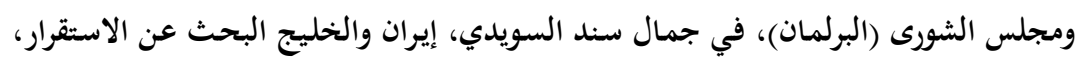

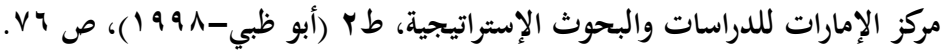

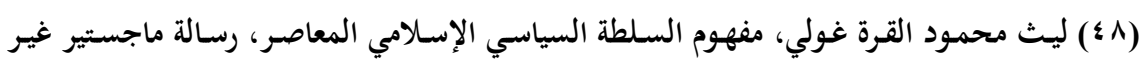

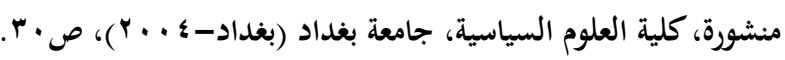




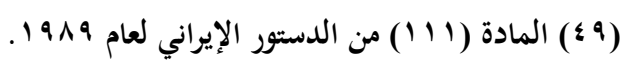

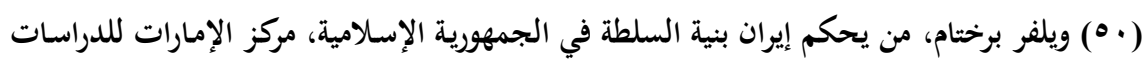

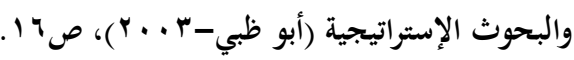

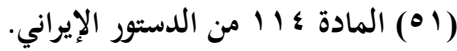

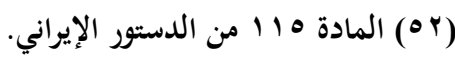

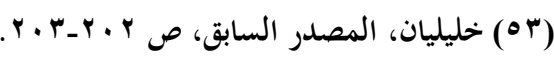

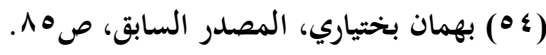

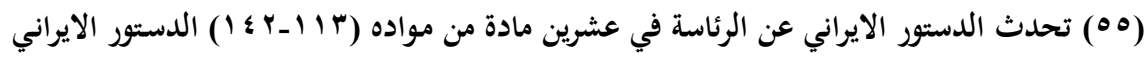

$$
\begin{aligned}
& \text { لعام 1919 19 . }
\end{aligned}
$$

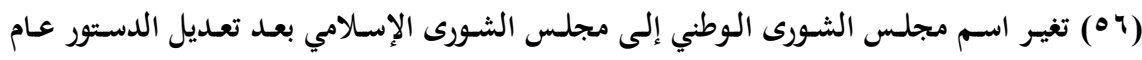

$$
\begin{aligned}
& \text {.1919 }
\end{aligned}
$$

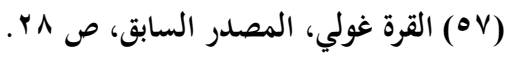

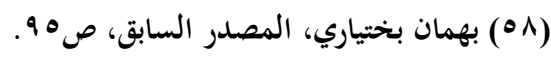

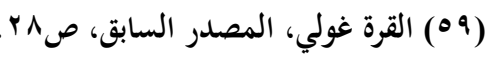

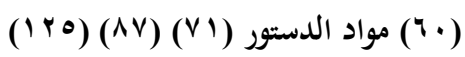

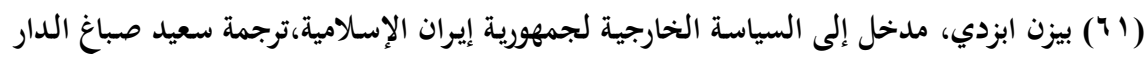

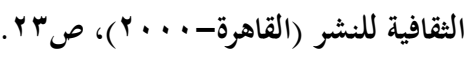

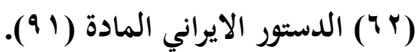

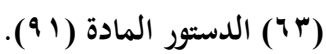

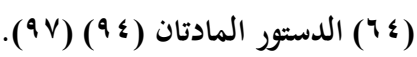

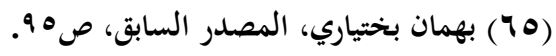

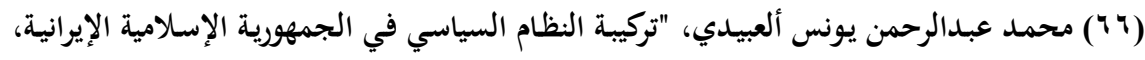

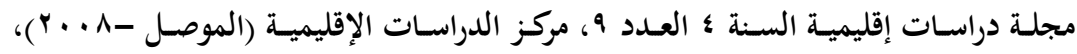

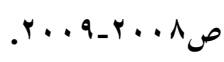

(TV) الدستور الايراني المادة ـ (11، للمزيد عن الوظائف الدستورية لمجمع تشخيص مصلحة النظام

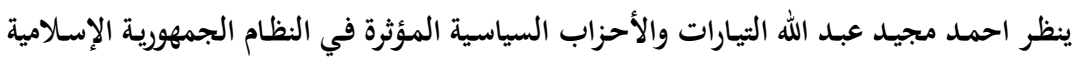

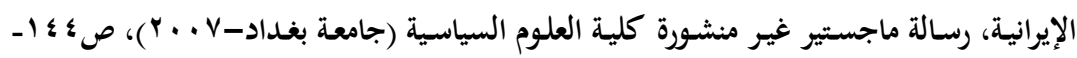


عبدالرزاق خلف الطائي [ [

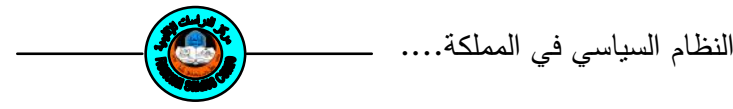

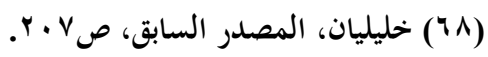

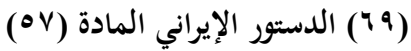

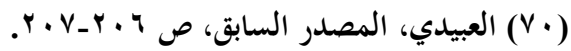

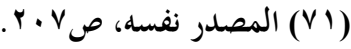

$$
\begin{aligned}
& \text { الرحدة (VY) }
\end{aligned}
$$

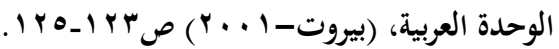

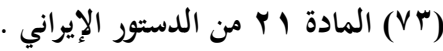

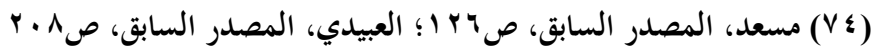

$$
\begin{aligned}
& \text { (V0) }
\end{aligned}
$$

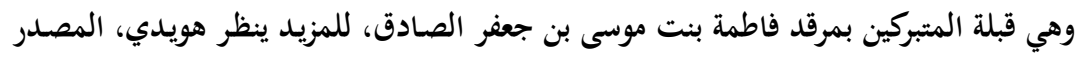

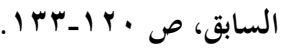

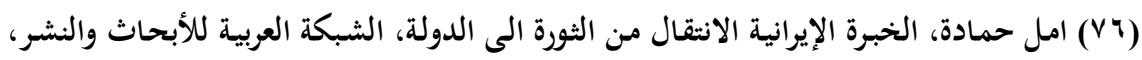

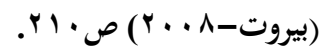

$$
\begin{aligned}
& \text { (VV) }
\end{aligned}
$$

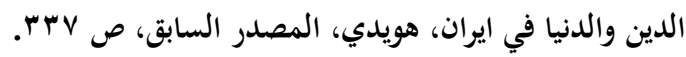

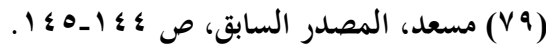

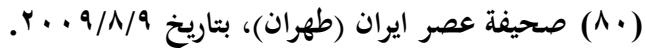

